\title{
IMPACT OF CLIMATIC FACTORS ON THE SUCCESS OF HUNTING VARIOUS GAME SPECIES IN CZECH REPUBLIC
}

\author{
RÖSSLOVÁ, M..$^{1}$ - VACEK, S. ${ }^{2}$ - VACEK, Z. ${ }^{2 *}-$ PROKŮPKOVÁ, A. ${ }^{2}$ \\ ${ }^{1}$ Czech University of Life Sciences Prague, Faculty of Environmental Sciences \\ Kamýcká 129, 16521 Prague 6 - Suchdol, Czech Republic \\ ${ }^{2}$ Czech University of Life Sciences Prague, Faculty of Forestry and Wood Sciences \\ Kamýcká 129, 16521 Prague 6 - Suchdol, Czech Republic \\ *Corresponding author \\ e-mail:vacekz@fld.czu.cz \\ (Received $14^{\text {th }}$ Nov 2019; accepted $12^{\text {th }}$ Feb 2020)
}

\begin{abstract}
The study evaluates the impact of climatic factors on the success of hunting in the Doupov Hills in the Czech Republic. The aim was to assess the impact of climatic factors on the success of individual and group hunting of various game species and their sex and age between 2005-2012. Overall, 27 thousand animals of the following game species were analyzed: red deer (Cervus elaphus L.), sika deer (Cervus nippon Temminck), fallow deer (Dama dama L.), mouflon (Ovis musimon L.), roe deer (Capreolus capreolus L.), wild boar (Sus scrofa L.), European badger (Meles meles L.) and red fox (Vulpes vulpes L.). The results show that mostly temperature co-determines the success of both hunting methods. Atmospheric pressure represents another important factor of influence, especially in group hunting. Snow cover supports variability of the probability of game hunting success. The success of hunting increased with decreasing temperature, increasing snow cover and increasing atmospheric pressure. Conversely, precipitation and wind speed had low effect on the success of hunting. Individual hunting was associated with significantly better climatic conditions in comparison to group hunting. Moreover, male game species were hunted in more favourable climatic conditions compared to female. Findings on the influence of climatic factors on the success of hunting can support planning the suitable time and method of hunting, thus increasing the success of hunting in montane and submontane regions of Central Europe.
\end{abstract}

Keywords: hunting method, ungulate, temperature, precipitation, Czech Republic

\section{Introduction}

Over the past decades and even centuries, European landscape has undergone significant changes due to the intensification of agriculture and land use (Ramankutty and Foley, 1999; Cukor et al., 2019a). As the landscape was being transformed and the demand for food was growing, agricultural production was increasing, field blocks widening, and structure of the crops changing (Levers et al., 2016; Wrzesien and Denisow, 2016). The new situation proved favourable for the ungulates that adapted well, and their populations increased in most European countries (Bleier et al., 2012; Hagen et al., 2014; Heurich et al., 2015; Thulin et al., 2015; Baltzinger et al., 2016).

The increase in numbers of large mammals does not derive only from the changes in landscape and intensification of agriculture - game populations are further influenced, for example, by climatic conditions (Hone and Clutton-Brock, 2007; Borowik et al., 2013; Koons et al., 2015). The 20th century witnessed gradual changes of climate; in most cases, studies have used summary factors such as mean temperature or total rainfall (Thomas et al., 2004, 2006). The changes influenced population dynamics (Balmford et al., 2003; Forsman and Mönkkönen, 2003; Sauerbrei et al., 2014), ecosystem functioning (Peñuelas et al., 2002; Hays et al., 2005) and also natural systems 
(Böhning-Gaese and Lemoine, 2004; Hays et al., 2005; Parmesan, 2006). Recently, there has been a substantial increase in the amount of literature on climate change affecting populations of vertebrates. For large herbivorous mammals, most attention has been paid to distribution responses to climate variation. Much less information is available about how climate affects animal behaviour, i.e. the climate mechanisms (Rivrud et al., 2010, 2014). The dynamics of animal populations are influenced by climatic conditions, on both the local and regional scale (Newton, 1998; Hallett et al., 2004).

Climatic conditions during the year have a significant impact on the populations of ungulates and their dynamics, either directly through changes in mortality or indirectly through the quantity and quality of food (Post and Stenseth, 1999; Hone and CluttonBrock, 2007; Borowik et al., 2013). Harsh winter conditions, for instance, have influenced the survival rate of domestic sheep (Ovis aries L.) (Milner et al., 1999; Coulson et al., 2001), red deer (Cervus elaphus L.) (Forchhammer et al., 1998) and roe deer (Capreolus capreolus L.) (Gaillard et al., 1993) and increased the numbers of mountain-dwelling woodland caribou (Rangifer tarandus caribou Gmelin) (Hegel et al., 2010). Autumn weather negatively influenced the reproduction rate of white-tailed deer (Odocoileus virginianus Zimmermann), while spring weather conditions supported successful reproduction (Simard et al., 2010). For red deer, the weight at birth was affected by rainfall in winter and spring temperatures (Sims et al., 2007).

Pettorelli et al. (2007), for example, report that forest mammals are very sensitive to the climate change of primary productivity and the phenological timing of green plants as their principal source of food. The annual fluctuation in weather affected the time and rate of the growth of plants that influenced juvenile growth of bighorn sheep (Ovis canadensis Shaw) and mountain goats (Oreamnos americanus Blainville), survival of bighorn sheep and Alpine ibex (Capra ibex L.) (Pettorelli et al., 2007) and the age of first reproduction of red deer (Langvatn et al., 1996).

Another major reason for the changes in populations of ungulates is the absence of natural predators, i.e. beasts of prey that play a key role in regulating the abundance of the ungulate populations (Buckland et al., 1996; Nilsen et al., 2009; Heurich et al., 2012). Gradually, hunting management became a tool to control game populations and regulate their distribution (Hothorn and Müller, 2010; Bischof et al., 2012; Heurich et al., 2015). In recent years, the importance of hunting management has been mentioned especially in the context of ever-increasing game-induced damage to field crops (Herrero et al., 2006; Bleier et al., 2012) and orchards (Mower et al., 1997; Marada et al., 2019). Moreover, increasing game populations significantly negatively affect forests by browsing of natural regeneration (Vacek et al., 2014, 2015; Ambrož et al., 2015; Slanař et al., 2017) and by bark stripping of young stands (Gerhardt et al., 2013; Månsson and Jarnemo, 2013; Cukor et al., 2019b, 2019c). The damage is caused not only by the native species of cloven-hoofed game but also by species introduced to the European continent in the past (Putman and Moore, 1998; Pitra and Lutz, 2005; Ward, 2005; Pérez-Espona et al., 2009). Due to the aforementioned, it is important to thoroughly monitor game populations using modern technology to determine appropriate wildlife management (Linchant et al., 2015; Cukor et al., 2019d).

Hunting management is a complex process driven by interactions between the dynamics of the natural system and stakeholders' decision-making and behaviour (Keuling et al., 2013; Quirós-Fernández et al., 2017). The effects of hunting pressure on spatial behaviour depend on several factors, including the hunting method (Root et 
al., 1988; Millspaugh et al., 2000; Vieira et al., 2003), level of hunting pressure (Johnson et al., 2004), local laws and hunting philosophy (Williams et al., 2013). The social structure is also important for animals living in a group: the loss of an individual may have different consequences depending on the hierarchical role it played within the group (Tuytten and McDonald, 2000). Findings on game behaviour that could improve hunting success were investigated e.g. in sika deer (Cervus nippon Temminck), whose pasture practice was observed during autumn and winter, using a Global Positioning System (GPS) tracking collar. During the hunting season, the collared deer stayed in a hiding place and avoided the pasture the entire day, while after the hunting season, the collared deer preferred sunny and calm pastures during the day as there was no human disturbance (Kamei et al., 2010).

A successful hunt is also co-determined by the habitat characteristics of the hunting district (Vercauteren and Hyngstrom, 1998; Millspaugh et al., 2000; Conner et al., 2001) and current climatic conditions. An open site such as a field is exposed to harsh weather more intensively in comparison to forest stands (Solberg et al., 2010). Weather can also affect the behaviour of the hunter (Rivrud et al., 2010) but, as far as we know, no study on the extent to which the hunter's behaviour is influenced by specific weather conditions has been published. In accordance with a general notion, hunting at moonlit nights seems to be more successful than when the sky is overcast (Theuerkauf et al., 2003). Hunting is always more intensive over the weekend compared to working days regardless of weather (Ciuti et al., 2012). Ciuti et al. (2012) also state that hunting success depends on the behaviour of animals, which is different in an open site and in the forest. Animals of different age and sex behave differently depending on the type of environment. Younger individuals are less alert than the older and more experienced individuals (Ciuti et al., 2012), therefore they can be hunted more successfully than older individuals.

It is well known that some habitat features, including biotope characteristics and climate change, generally affect the predator-prey dynamics (Kunkel and Pletscher, 2000; Lebel et al., 2012; Kuijper et al., 2013). On hunting grounds, the hunters are sometimes considered to be predators and hunted animals the prey (Nugent and Choquenot, 2004). Ecological differences on the site affect the hunters as well. For example, extreme cold or heavy rainfall is less attractive for hunting than hot and rainfree weather (Rivrud et al., 2014).

The success of game observation and hunting depends on numerous factors, some of which can be taken advantage of by the hunters, improving their hunting success (Merkel, 2010). These include, for example, familiarity with the environment, biology of game and its resting haunts, and appropriate timing of the hunt (Bunnefeld et al., 2009). There are factors unsusceptible to our will, especially weather conditions at a given time and place (Rivrud et al., 2014).

Knowledge of the influence of detailed climatic characteristics on the success of hunting of various game species is still inadequate. The aim of this work is therefore to assess the influence of detailed climatic factors (maximum and minimum wind speed in $\mathrm{m} \mathrm{s}^{-1}$, mean, minimum and maximum daytime temperature in ${ }^{\circ} \mathrm{C}, 30$-minute-interval temperature progress during the course of the day in ${ }^{\circ} \mathrm{C}$, daily precipitation in $\mathrm{mm}$, total daily snow cover in $\mathrm{cm}$, atmospheric pressure reduced to sea level in $\mathrm{Pa}$ ) on the method and success of hunting of various game species (red deer, sika deer, fallow deer /Dama dama L./, mouflon /Ovis musimon L./, roe deer, wild boar /Sus scrofa L./, European badger /Meles meles L./, red fox /Vulpes vulpes L./) and their sex (male, female) and 
age (adults, young animals) in 2005-2012 in the hunting grounds of the Karlovy Vary division of Military Forests and Estates, state enterprise (VLS) in Doupov Hills. In terms of game and hunting management it is important to know detailed information about the history of the study territory (Pohja-Mykrä et al., 2005; Rivrud et al., 2013). The settlement of the Doupov Hills, especially of their marginal parts and the Ohrre River valley, dates back to the Neolithic (5500-4000 years BC). After the Thirty Years' War, the area was almost completely depopulated, and people were returning very slowly. After 1880, the area witnessed another depopulation as the inhabitants were leaving to seek work in nearby industrial cities. After the Second World War, prevailing German population was expelled. By Government resolution of March 4, 1953, Hradiště military training ground was set up on $290.4 \mathrm{~km}^{2}$, gradually expanding to $331.6 \mathrm{~km}^{2}$ (Culek et al., 2013), which helped to preserve natural landscape of the Doupov Hills and protect it from processes typical of the $20^{\text {th }}$ century landscape (large-scale agricultural and forestry management, fertilization, application of chemical methods and amelioration) to the present day (Tscharntke et al., 2005; Lundmark et al., 2013; Cukor et al., 2017; Vacek et al., 2019).

The hypotheses of this research were that:

1) Favourable climatic characteristics (temperature, atmospheric pressure and precipitation) increase the success of particular game species hunting.

2) The hunting method is selected not only by climatic characteristics but also by particular hunting ground conditions, forest stand characteristics, and sex and age of particular game species.

\section{Materials and Methods}

\section{Study area}

The Doupov Hills are a geomorphological complex in the south of the Ore Mountains system in the north-west of the Czech Republic (Fig. 1). The area of the Doupov Hills is $607 \mathrm{~km}^{2}$. Most of the range is situated on the right bank of the Ohře River, while a minor part is located also on its left bank. The Doupov Hills are composed of tertiary volcanic materials: lava (tephrites, leucitites) and tuff. The range is shaped as flat circular highlands, with the highest peaks reaching from 700 to $934 \mathrm{~m}$ a.s.l. (Vacek et al., 2003). According to Köppen world climate classification (Köppen, 1936), the study area predominantly belongs to humid continental climate characterized by a moderately warm to hot climate summers and cold winters (classification Dfb), while the highest parts belong to a boreal climate area characterized by long, usually very cold winters, and short, cool to mild summers (classification Dfc). Windward southwest and northwest slopes are wetter than the eastern, rain-shadowed slopes. The sunny exposures where the foothills verge into the basins are warmer than the inversion narrow steep-walled valleys and terrain depressions affected by water. The average annual air temperature ranges from 5.0 to $6.9^{\circ} \mathrm{C}$ and the precipitation ranges from 550 to $960 \mathrm{~mm}$ (Fig. 1). The average relative air humidity is in a range of $67-84 \%$. The number of days with snow cover is around 80 (mean occurrence between October $27^{\text {th }}$ and April $30^{\text {th }}$ ) and the average maximum snow depth is between $25-45 \mathrm{~cm}$. The length of sunshine ranges from 30 hours in December to 225 hours in June (annually 1,554 hours). The length of the vegetation season varies from 110 to 150 days. Destructive winds come mainly from the west (Plíva and Žlábek, 1986; Tolasz, 2007). 


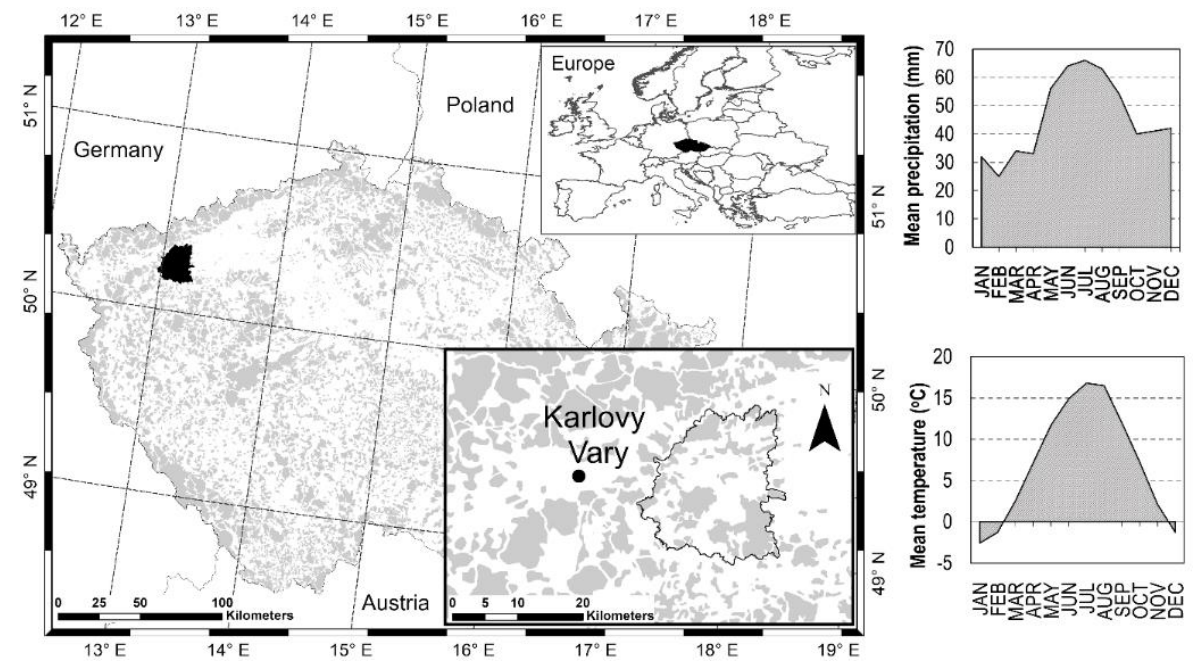

Figure 1. The area of interest the Doupov Hills in the Czech Republic; the grey colour indicates the forest cover; mean monthly climate values (air temperature and precipitation) in 1939-2017 (right)

Regarding soils, cambisols prevail in the lower and middle parts of the range, followed by cryptopodzols and podzols in the higher parts. Pseudogleys, gleys and organozems are common in terrain depressions (Demek et al., 2006). Plants of the area have typical features of Hercynian flora of montane and submontane zones. There are acidophilous oak forests on sunny exposures, verging into herb-rich beech forests and dominant woodrush beech forests on more nutrient soils. As the elevation rises, there are acidophilic montane beech forests, and in damp localities we observe water-drenched spruce forests and transitional peat bogs. Along the streams there are meadows and alder woods, and talus forests on the steep slopes. Sparse hornbeam oak, acidophilic and relic pine forest (Průša, 2001) should also be mentioned.

The landscape, essentially uninhabited and used only for training the troops, has acquired unusual features. The most striking - for a mountain range - are vast shrubby areas, pools in missile craters, rocket ranges battered by frequent fires, or exposed surface of tank roads, i.e. phenomena non-existent in civilian countryside. We also observe wellpreserved genuine biotopes at sustaining stages of succession, such as herb-rich beech forests, ash-alder alluvial forests, oak-hornbeam, oak and talus forests. The most interesting vegetation is traditionally found on rocky steppes, dry grasslands and wetlands. We can also see managed species-rich meadows and extensively managed ponds rich in macrophyte vegetation (Matějů et al., 2016).

\section{Hunting management}

Hunting management reflects the specific regime of a military district. The Hradiště hunting grounds has a total area of 36,029 ha, of which $41.2 \%$ is forest land, $5.8 \%$ farm land, $0.2 \%$ water bodies and $52.8 \%$ other areas, largely covered by shrubs. The specific use of the landscape with its vast shrubby areas makes hunting considerably more complicated. Hunting from hides and stalking is used for individual hunting, while in the case of group hunting the hunters opt for battues and dog driving. Female animals, deer fawns and wild boar piglets are hunted in fee-charged battues and individually by gamekeeping staff; male animal hunting is usually subject to a charge. In the period 
2005-2012, a total of 27,729 animals of the following species were hunted in this area: red deer (6,835 ind.), sika deer (8,294 ind.), fallow deer (103 ind.), mouflon (167 ind.), roe deer (4,292 ind.), wild boar (7,297 ind.), European badger (68 ind.) and red fox (673 ind.) (Table 1). Of these, animals shot for sanitary reasons were subtracted from the statistical evaluation, i.e. approximately 150 animals in the Hradiště hunting grounds every year. Northern raccoon (Procyon lotor L.) and pine marten (Martes martes L.) were also subtracted because of the low number of hunted animals ( $<20$ ind.). Moreover, in accordance with Act No. 449/2001 Coll., the Northern raccoon can be hunted only by professional gamekeepers or hunting guard.

Table 1. The numbers of the hunted animals in Hradište hunting grounds by the particular game species in 2005-2012

\begin{tabular}{|c|c|c|c|c|c|c|c|c|c|}
\hline \multirow{2}{*}{ Game species } & \multicolumn{8}{|c|}{ Year } & \multirow{2}{*}{ Total } \\
\hline & 2005 & 2006 & 2007 & 2008 & 2009 & 2010 & 2011 & 2012 & \\
\hline Wild boar male & 14 & 5 & 2 & 4 & 14 & 11 & 15 & 16 & 81 \\
\hline Wild boar female & 76 & 25 & 36 & 26 & 33 & 37 & 58 & 110 & 401 \\
\hline Wild boar fawn & 241 & 106 & 139 & 123 & 67 & 167 & 106 & 416 & 1,365 \\
\hline Wild boar piglet & 795 & 303 & 651 & 676 & 633 & 696 & 675 & 1,021 & 5,450 \\
\hline Mouflon male & 4 & 0 & 0 & 5 & 3 & 12 & 2 & 8 & 34 \\
\hline Mouflon female & 22 & 9 & 8 & 12 & 12 & 9 & 6 & 2 & 80 \\
\hline Mouflon fawn & 14 & 5 & 5 & 6 & 9 & 5 & 5 & 4 & 53 \\
\hline Roe deer male & 110 & 84 & 118 & 180 & 225 & 200 & 202 & 226 & 1,345 \\
\hline Roe deer female & 225 & 70 & 176 & 230 & 273 & 195 & 204 & 316 & 1,689 \\
\hline Roe deer fawn & 192 & 49 & 129 & 155 & 211 & 178 & 126 & 218 & 1,258 \\
\hline Red deer male & 119 & 76 & 126 & 169 & 194 & 193 & 290 & 287 & 1,454 \\
\hline Red deer female & 223 & 206 & 248 & 310 & 361 & 471 & 491 & 481 & 2,792 \\
\hline Red deer fawn & 268 & 212 & 203 & 281 & 338 & 403 & 421 & 463 & 2,589 \\
\hline Sika deer male & 144 & 129 & 180 & 224 & 219 & 233 & 245 & 309 & 1,683 \\
\hline Sika deer female & 217 & 161 & 330 & 404 & 439 & 636 & 655 & 772 & 3,614 \\
\hline Sika deer fawn & 235 & 176 & 254 & 339 & 380 & 535 & 491 & 587 & 2,997 \\
\hline Fallow deer male & 3 & 1 & 1 & 1 & 3 & 3 & 5 & 3 & 20 \\
\hline Fallow deer female & 5 & 2 & 2 & 4 & 10 & 8 & 10 & 7 & 48 \\
\hline Fallow deer fawn & 5 & 3 & 9 & 6 & 2 & 3 & 3 & 5 & 36 \\
\hline Red fox & 85 & 34 & 69 & 57 & 93 & 140 & 73 & 122 & 673 \\
\hline European badger & 0 & 0 & 4 & 11 & 9 & 8 & 12 & 24 & 68 \\
\hline Total & 2,997 & 1,656 & 2,690 & 3,223 & 3,528 & 4,143 & 4,095 & 5,397 & 27,729 \\
\hline
\end{tabular}

\section{Data collection}

The analysis of the impact of climatic data on the success of game hunting was based on climatic data provided by the Karlovy Vary meteorological station, Olšová vrata (603 $\mathrm{m}$ above sea level), which conveniently represents the climatic conditions in the Doupov Hills. Climatic data (maximum and minimum wind speed in $\mathrm{m} \mathrm{s}^{-1}$, mean, minimum and maximum daytime air temperature in ${ }^{\circ} \mathrm{C}, 30$-minute-interval temperature progress in the course of the day in ${ }^{\circ} \mathrm{C}$, daily precipitation in $\mathrm{mm}$, total daily snow cover in $\mathrm{cm}$, atmospheric pressure reduced to sea level in $\mathrm{hPa}$ and daily atmospheric pressure change) cover the period of 2005-2012. Data on hunting various game species (red deer, sika deer, fallow deer, mouflon, roe deer, wild boar, European badger, red fox), their sex (male, female) and age (adults, young animals), method and date of hunting in 2005-2012 were obtained from the VLS. In the VLS hunting grounds of the Doupov Hills, all hunted animals are recorded. Hunting seasons are strictly observed, as in the rest of the Czech Republic (Table 2). For generalized comparing, game species (including their age and sex) were divided in relation to hunting season to five groups. 
Table 2. The dates of hunting season for different species of game in the Czech Republic in 2005-2012

\begin{tabular}{|c|c|c|}
\hline The date of hunting & Game species & Group \\
\hline 01 Aug - 15 Jan & red deer, male and female & 1 \\
\hline 01 Aug - 31 Mar & red deer fawn & 2 \\
\hline 01 Aug - 15 Jan & sika deer, male and female & 1 \\
\hline 01 Aug - 31 Mar & sika deer fawn & 2 \\
\hline 16 Aug - 31 Dec & fallow deer, male and female & 1 \\
\hline 16 Aug - 31 Mar & fallow deer fawn & 2 \\
\hline 16 May - 30 Sep & roe deer & 4 \\
\hline $01 \mathrm{Sep}-31 \mathrm{Dec}$ & roe deer fawn and female & 1 \\
\hline 01 Aug - 31 Dec & mouflon, male and female & 1 \\
\hline $01 \mathrm{Aug}-31 \mathrm{Mar}$ & mouflon fawn & 2 \\
\hline $01 \mathrm{Jan}-31 \mathrm{Dec}$ & wild boar & 3 \\
\hline $01 \mathrm{Jan}-31 \mathrm{Dec}$ & red fox & 3 \\
\hline $01 \mathrm{Sep}-30 \mathrm{Nov}$ & European badger & 5 \\
\hline
\end{tabular}

\section{Statistical data processing}

Testing for differences in values of selected climatic parameters was performed via Kruskal-Wallis tests with subsequent multiple comparisons. Game species were analysed in relation to their mean deviations from average climatic characteristic on the day of individual hunting and group hunting. Principal component analysis (PCA) was used to describe overall characteristics of analysed multivariate data. Climatic data (air temperature, precipitation, snow cover, wind speed, atmospheric pressure, atmospheric pressure change) were standardized according to hunting season of each species prior to statistical analyses. Furthermore, the success of hunting was focused on the period (November and December) with the highest occurrence of hunted animals (over 54\% of the annual number), where the number of daily hunted animals was compared with climatic data by linear regression. All statistical tests were performed on significance level $\alpha=0.05$. Statistically significant differences among game species in relation to climatic characteristic were marked by different indices (homogenous groups). Error bars indicate standard error of mean (SE). Computations were performed in $\mathrm{R}$ software ( $\mathrm{R}$ Core Team, 2018).

\section{Results}

\section{Climatic characteristics of the date of hunting for game species}

The climatic characteristics for each game species at the time of hunting are shown in Figs. 2-4. Fig. 2 shows average air temperatures in ${ }^{\circ} \mathrm{C}$ on the hunting day by particular game species, varying considerably in relation to hunting time for each species. Average temperatures in the hunting time range from $0.5^{\circ} \mathrm{C}$ for wild boar piglets to $15.3^{\circ} \mathrm{C}$ for roe deer males. The greatest standard error of the mean (SE) of average temperature were found in fallow deer fawn (SE 1.22), mouflon male (SE 1.15) and fallow deer female (SE $1.00)$.

Comparing game species with the similar hunting season (same group in Table 2), red deer male showed the highest average air temperature in group 1, followed by fallow deer male, while the lowest temperature was observed in roe deer female and mouflon female. In hunting group 1 , higher average air temperature $\left(2.4^{\circ} \mathrm{C}\right)$ was observed in all cases in male game species compared to female. In group 2, the highest temperature on hunting 
day was in fallow deer fawn and the lowest in mouflon fawn. In wild boar, the highest temperature was found in the case of fawn and vice versa in piglet.

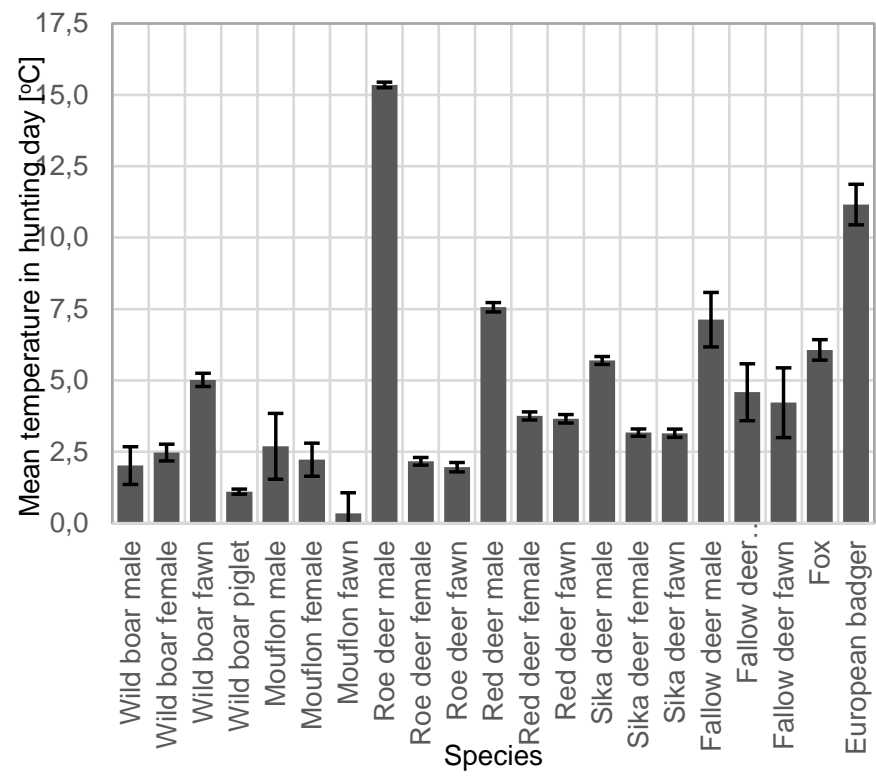

Figure 2. Average air temperatures in ${ }^{\circ} \mathrm{C}$ on the hunting day by particular game species in 2005-2012; error bars indicate standard error of the mean

Fig. 3 shows average rainfall in $\mathrm{mm}$ on the day of hunting by particular game species, varying only insignificantly in each species $(0.9-1.4 \mathrm{~mm})$, being slightly higher only for European badger and roe deer male $(1.8-2.1 \mathrm{~mm})$. The greatest SE of average rainfall were found in European badger (SE 0.45), fallow deer fawn (SE 0.47) and fallow deer male (SE 0.54).

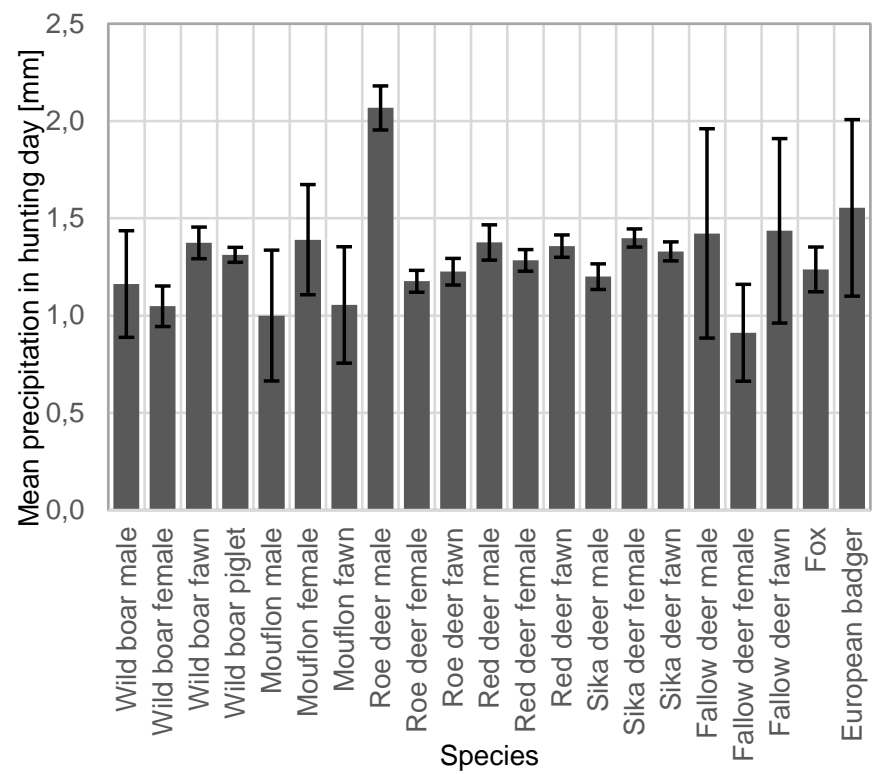

Figure 3. Average precipitation in mm on the hunting day by particular game species in 20052012; error bars indicate standard error of the mean 
Regarding hunting group 1, fallow deer male showed the highest average precipitation, followed by mouflon female, while the lowest precipitation was observed in fallow deer female and mouflon male. Similarly, in group 2, the highest precipitation on hunting day was in fallow deer fawn, while the lowest was found in mouflon fawn. In wild boar, the highest temperature was found in the case of fawn and vice versa in female.

Fig. 4 shows the average snow cover in $\mathrm{cm}$ on the day of hunting by game species, varying from 0 to $8 \mathrm{~cm}$ for particular species. It was the highest in mouflon male $(7.9 \mathrm{~cm})$ and mouflon fawn $(6.7 \mathrm{~cm})$; it was also fairly high in wild boar piglet $(6.0 \mathrm{~cm})$, sika deer fawn $(5.4 \mathrm{~cm})$, sika deer female $(5.3 \mathrm{~cm})$, roe deer fawn $(5.0 \mathrm{~cm})$, while it was zero in roe deer male $(0.0 \mathrm{~cm})$ and only $0.1 \mathrm{~cm}$ in European badger. The greatest $\mathrm{SE}$ of average snow cover was found in fallow deer male (SE 1.88), mouflon male (SE 1.44), mouflon fawn (SE 1.21) and fallow deer female (SE 1.14).

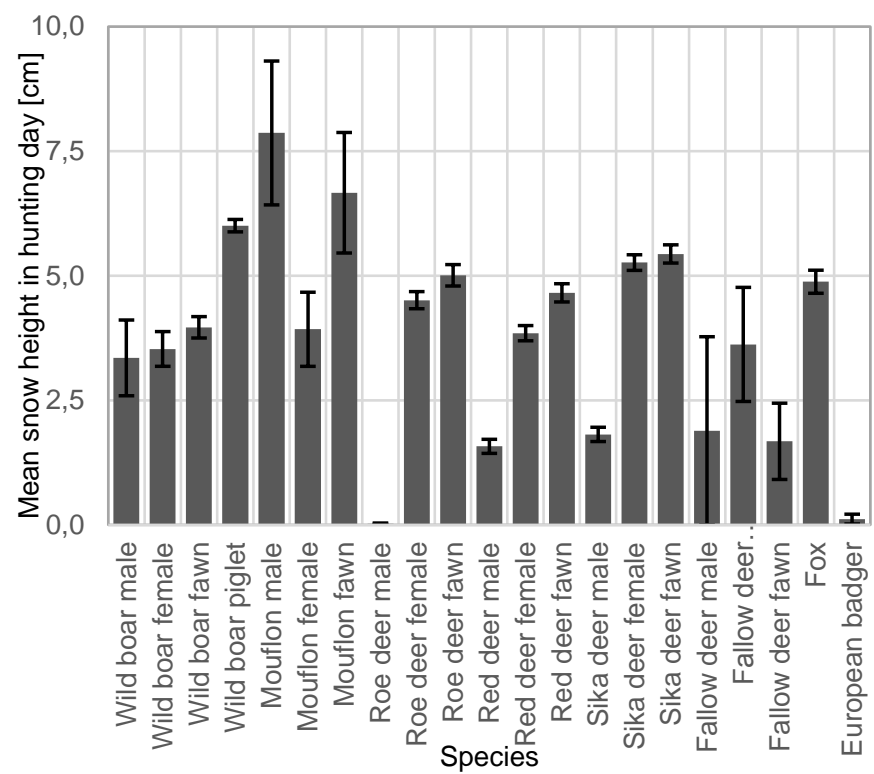

Figure 4. Average snow cover in cm on the hunting day by particular game species in 20052012; error bars indicate standard error of the mean

Comparing game species with the similar hunting season, fallow deer male showed the highest average snow cover in group 1, followed by fallow sika deer female, while the lowest snow height was observed in red deer male and sika deer male. In hunting group 1, higher average snow cover $(0.9 \mathrm{~cm})$ was observed in female game species compared to male (except mouflon). In group 2, the highest snow cover on hunting day was for mouflon deer fawn and the lowest for fallow fawn. In the wild boar group, the highest snow height was in the case of piglet and vice versa in male.

Fig. 5 shows the average atmospheric pressure in $\mathrm{hPa}$ on the hunting day by particular game species, varying inconsiderably and ranging from $1016.0 \mathrm{hPa}$ (in fallow deer fawn) to $1020.7 \mathrm{hPa}$ (in mouflon fawn). The greatest SE of average atmospheric pressure was found in fallow deer male, mouflon male, mouflon fawn and fallow deer fawn (SE 1.48-1.85).

Regarding hunting group 1, sika deer male showed the highest average atmospheric pressure, followed by fallow deer male, while the lowest atmospheric pressure was observed in roe deer female and sika deer female. In hunting group 1, higher average 
atmospheric pressure $(1.3 \mathrm{hPa})$ was observed in male game species compared to female. In group 2, the highest precipitation on hunting day was in mouflon fawn, while the lowest was found in fallow deer fawn. In group 3, the highest atmospheric pressure was in the case of wild board male, while it was lowest in female.

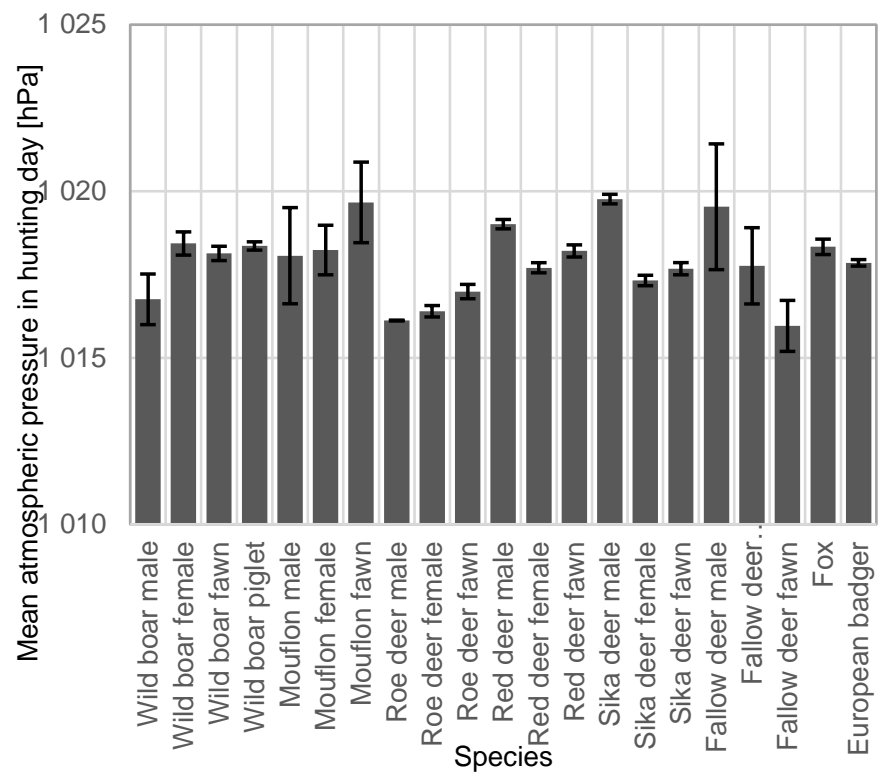

Figure 5. Average atmospheric pressure in $\mathrm{hPa}$ on the hunting day by particular game species in 2005-2012; error bars indicate standard error of the mean

\section{Comparison of climatic characteristics of the hunting days by game species}

\section{Temperature impact}

Standardized climatic characteristics for each game species at the time of hunting are shown in Figs. 6-9. Fig. 6 shows average deviations from the average temperature in ${ }^{\circ} \mathrm{C}$ on the hunting day for particular game species (for individual hunting and group hunting). $\mathrm{Y}$-axis shows the mean temperature deviation on the hunting day from the average temperature over the whole investigated period. Game species reaching values above 0 are hunted when temperature is higher than mean value during the hunt and vice versa; the particular value then shows "how much temperature is higher or lower" it is than at usual hunting time.

Most game species were individually hunted at lower-than-average temperatures for the given time of hunting, except for yearling boar $\left(0.1^{\circ} \mathrm{C}\right)$, roe deer male $\left(0.4^{\circ} \mathrm{C}\right)$, fallow deer female $\left(1.1^{\circ} \mathrm{C}\right)$, red deer male $\left(1.8^{\circ} \mathrm{C}\right)$, fallow deer male $\left(1.8^{\circ} \mathrm{C}\right)$, fallow deer fawn $\left(2.8^{\circ} \mathrm{C}\right)$ and European badger $\left(3.6^{\circ} \mathrm{C}\right)$, which were hunted at higher-than-average temperatures. Markedly lower-than-average temperatures are suitable especially for individual hunting of wild boar piglets $\left(-6.0^{\circ} \mathrm{C}\right)$, mouflon females $\left(-4.3^{\circ} \mathrm{C}\right)$, wild boar males $\left(-3.5^{\circ} \mathrm{C}\right)$, mouflon fawns $\left(-3.1^{\circ} \mathrm{C}\right)$, mouflon males $\left(-3.0^{\circ} \mathrm{C}\right)$, sika deer females $\left(-2.6^{\circ} \mathrm{C}\right)$ and wild boar females $\left(-2.0^{\circ} \mathrm{C}\right)$. The standard errors of the mean are rather high in fallow deer fawns (SE 1.6), fallow deer females (SE 1.5), wild boar males (SE 1.3) and mouflon males (SE 1.3).

In terms of group-hunting, markedly lower-than-average temperatures are suitable especially for hunting of mouflon males $\left(-10.5^{\circ} \mathrm{C}\right)$, wild boar yearlings $\left(-6.8^{\circ} \mathrm{C}\right)$, wild boar 
piglets $\left(-6.8^{\circ} \mathrm{C}\right)$, red deer males $\left(-6.5^{\circ} \mathrm{C}\right)$, red foxes $\left(-6.4^{\circ} \mathrm{C}\right)$, sika deer males $\left(-6.3^{\circ} \mathrm{C}\right)$, wild boar males $\left(-6.2^{\circ} \mathrm{C}\right)$, wild boar females $\left(-6.0^{\circ} \mathrm{C}\right)$, sika deer females $\left(-5.9^{\circ} \mathrm{C}\right)$, red deer females $\left(-5.8^{\circ} \mathrm{C}\right)$, roe deer fawns $\left(-5.7^{\circ} \mathrm{C}\right)$, mouflon females $\left(-5.4^{\circ} \mathrm{C}\right)$, roe deer females $\left(-5.2^{\circ} \mathrm{C}\right)$, fallow deer males $\left(-4.8^{\circ} \mathrm{C}\right)$, fallow deer females $\left(-4.8^{\circ} \mathrm{C}\right)$, mouflon fawns $\left(-4.5^{\circ} \mathrm{C}\right)$, sika deer fawns $\left(-4.1^{\circ} \mathrm{C}\right)$ and red deer fawns $\left(-3.3^{\circ} \mathrm{C}\right)$. The standard errors of the mean are rather large in fallow deer males (SE 3.5), mouflon males (SE 1.6), mouflon fawns (SE 1.2) and fallow deer fawns (SE 1.0).
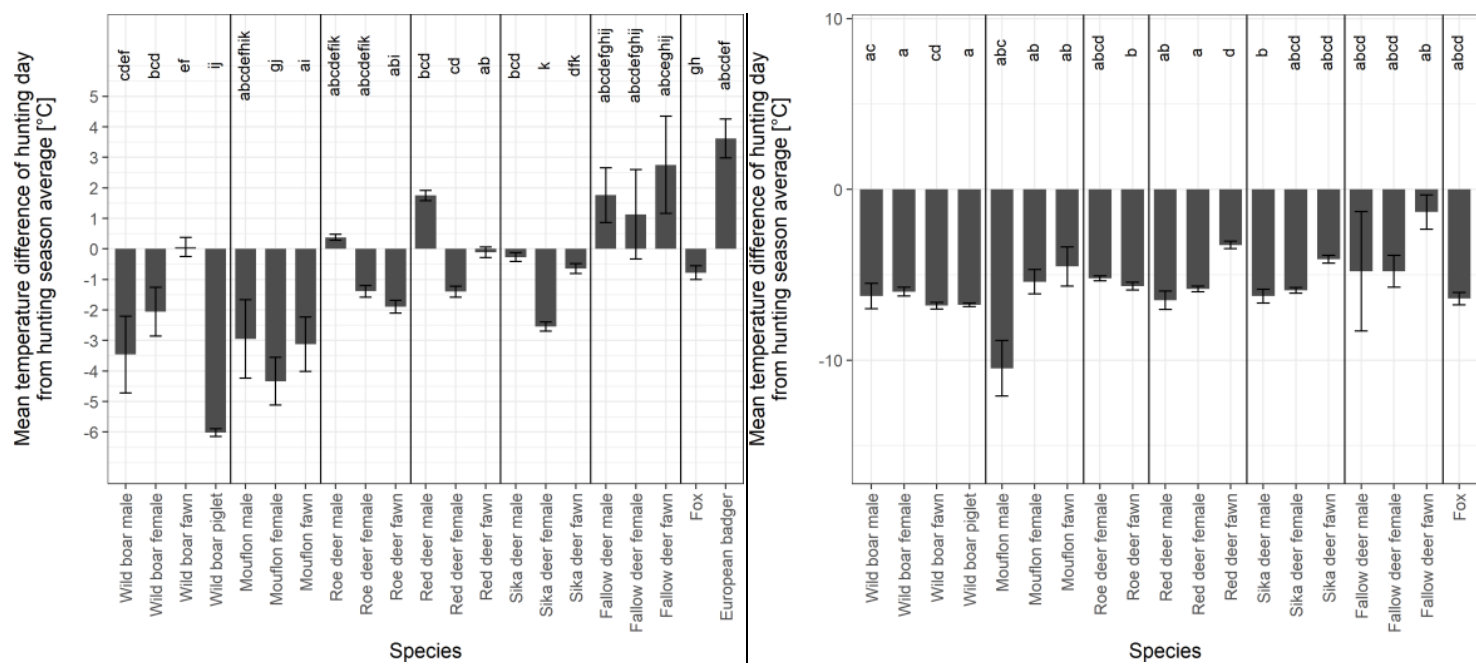

Figure 6. Mean deviations from the average temperature in ${ }^{\circ} \mathrm{C}$ on the day of individual hunting (left) and group hunting (right) by particular game species between 2005-2012; statistically significant differences among species are marked by different indices; error bars indicate standard error of the mean

In the case of individual hunting, statistically significant differences were observed in the deviations from the average temperature between values for wild boar piglet, whose respective values were significantly different from the values of all species, except mouflon female, mouflon male, mouflon fawn and wild boar male. Mouflon and wild boar are generally hunted at temperatures lower than usual in their hunting season. In contrast, European badger, fallow deer fawn, red deer male and fallow deer male are generally hunted in weather with higher temperature than usual. The values for red deer male proved to be different from red deer female, sika deer female and sika deer male, while in the case of red deer and sika deer, we observed significant differences in values for females and fawns.

Significant differences between temperature deviations from the average for the particular hunting time can be identified in the case of group hunting of wild boar yearling and piglet in comparison with red deer female, sika deer male and roe deer fawn. Also, we find a difference in the value for red deer fawn and sika deer fawn, whose values differ significantly from those found for adults.

\section{Precipitation impact}

Fig. 7 shows average deviations from precipitation in $\mathrm{mm}$ on the day of hunting for particular species. Most game species were hunted individually at lower-than-average precipitation sums except for European badger $(0.1 \mathrm{~mm})$ that is hunted at higher 
precipitation sums. Red deer fawns and sika deer fawns were hunted at boundary values of average precipitation. Significantly lower-than-average precipitation was suitable for hunting fallow deer females $(-0.7 \mathrm{~mm})$, mouflon males, fallow deer fawns, mouflon fawns $(-0.4 \mathrm{~mm})$, wild boar males, sika deer males, foxes $(-0.3 \mathrm{~mm})$, wild boar yearlings, mouflon females and wild boar females $(-0.2 \mathrm{~mm})$. The standard error of the mean was larger in fallow deer males, wild boar males (SE 0.6), mouflon males, mouflon females and European badgers (SE 0.4), mouflon fawns and fallow deer fawns (SE 0.3).

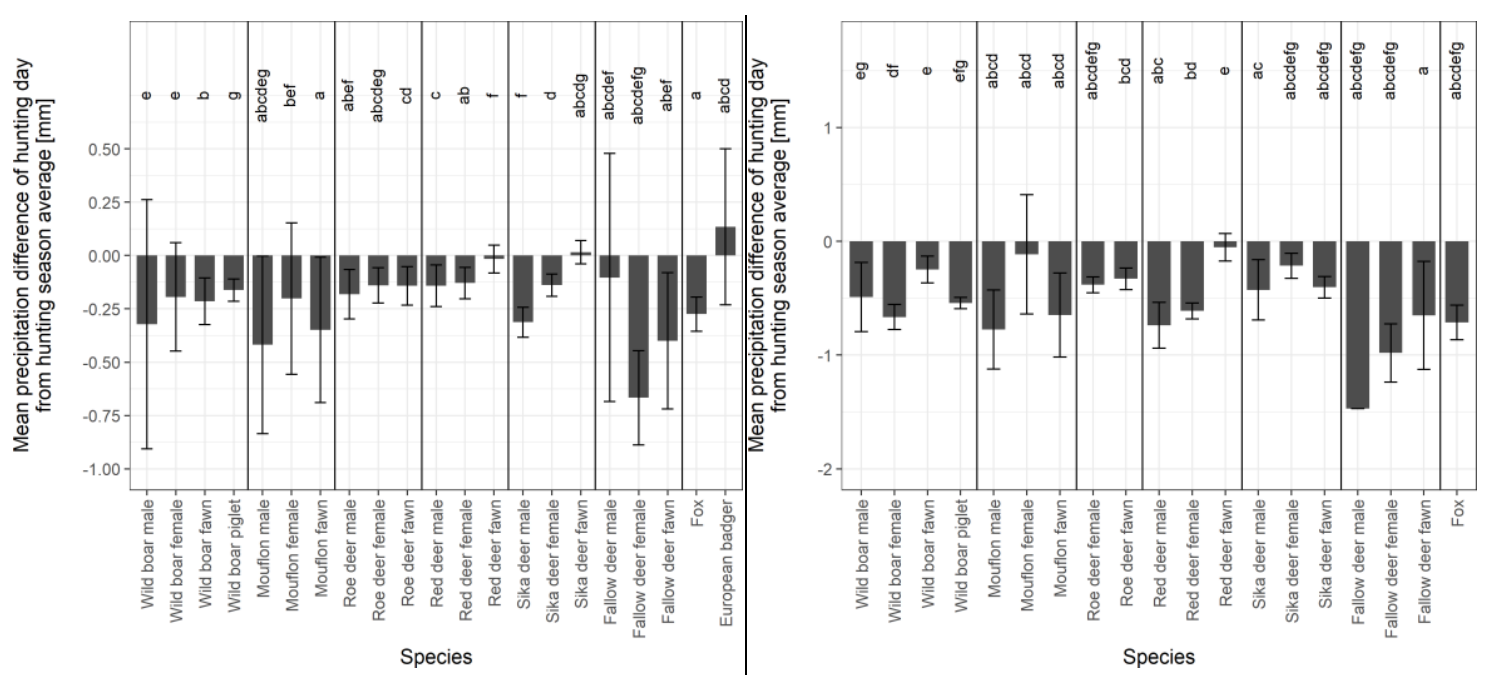

Figure 7. Mean deviations from the precipitation in $\mathrm{mm}$ on the hunting day of individual hunting (left) and group hunting (right) by particular game species in 2005-2012; statistically significant differences among species are marked by different indices; error bars indicate standard error of the mean

All game species were group-hunted at lower-than-average-precipitation. Markedly lower-than-average precipitation was suitable for hunting fallow deer males $(-1.5 \mathrm{~mm})$, fallow deer females $(-1.0 \mathrm{~mm})$, mouflon males $(-0.8 \mathrm{~mm})$, red deer males, foxes, wild boar females, fallow deer fawns, mouflon fawns $(-0.7 \mathrm{~mm})$, red deer females $(-0.6 \mathrm{~mm})$, wild boar piglets and wild boar males $(-0.5 \mathrm{~mm})$. The standard error of the mean was slightly higher in fallow deer fawns, mouflon females (SE 0.5), mouflon males, mouflon fawns (SE 0.4) and wild boar males (SE 0.3).

In the case of individual hunting, significant differences were not found between deviations from the average precipitation for red deer fawns and sika deer fawns, similarly to wild boar males and wild boar yearlings, and mouflon males, mouflon females and mouflon fawns, but in the case of wild boar yearlings and piglets there was a statistically significant difference, similar to that of roe deer males and roe deer fawns, whoes values did not differ from the value for the roe deer females. The values for red deer fawn and sika deer fawn differed from the values for the adult animals, but the values for red deer males and females showed no significant differences.

Group hunting also brought statistically significant results in wild boar yearlings and piglets, or red deer males and fawns in the case of red deer and sika deer. The average precipitation values were comparable, as in the previous case of fawns of both deer species. 


\section{Snow cover impact}

Fig. 8 shows average deviations from the snow cover in $\mathrm{cm}$ on the hunting day by particular game species. Half of the game species are hunted individually at the lower-than-average snow cover, the other half at the higher-than-average snow cover, as compared with the average. The higher-than-average snow cover suits hunting wild boar piglets $(3.3 \mathrm{~cm})$, mouflon males $(2.8 \mathrm{~cm})$, sika deer females $(2.5 \mathrm{~cm})$, mouflon females $(2.2 \mathrm{~cm})$, foxes $(1.7 \mathrm{~cm})$, fallow deer females $(1.5 \mathrm{~cm})$ and roe deer fawns $(1.2 \mathrm{~cm})$. The lower-than-average snow cover suits hunting fallow deer fawns $(-5.1 \mathrm{~cm})$, fallow deer males $(-2.2 \mathrm{~cm})$, wild boar males $(-1.5 \mathrm{~cm})$ and red deer males $(-1.3 \mathrm{~cm})$. Snow cover of around the average is suitable for hunting red deer fawns and roe deer males. The standard error of the mean is rather large in fallow deer females (SE 1.8), mouflon males (SE 1.6), mouflon fawns (SE 1.5), wild boar males, mouflon females (SE 0.9).
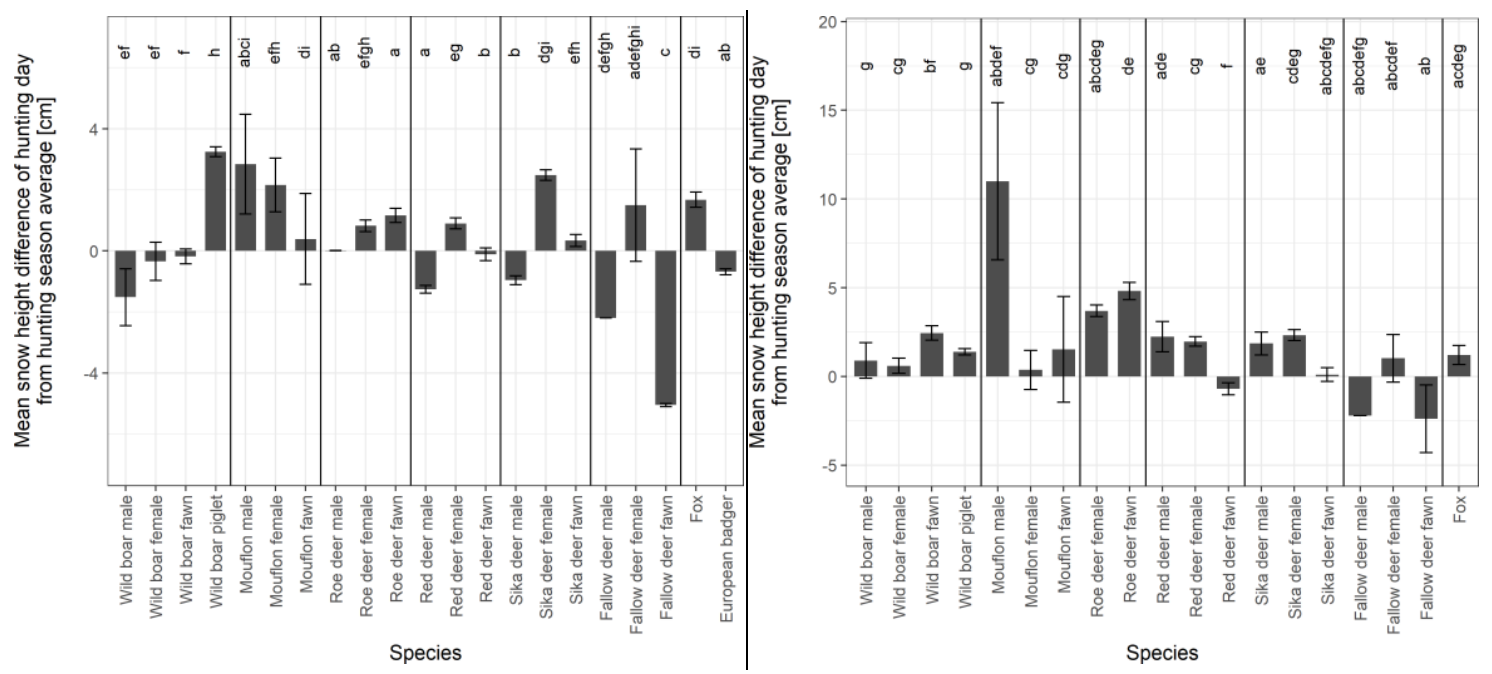

Figure 8. Mean deviations from the snow cover in $\mathrm{cm}$ on the hunting day of individual hunting (left) and group hunting (right) by particular game species in 2005-2012; statistically significant differences among species are marked by different indices; error bars indicate standard error of the mean

A vast majority of game species were group-hunted at higher-than-average snow cover. The highest levels of snow cover suited the group hunt of the mouflon male $(11.0 \mathrm{~cm})$, roe deer fawn $(4.8 \mathrm{~cm})$, roe deer female $(3.7 \mathrm{~cm})$, wild boar yearling $(2.5 \mathrm{~cm})$, sika deer female $(2.3 \mathrm{~cm})$, red deer male $(2.2 \mathrm{~cm})$ and sika deer male $(1.9 \mathrm{~cm})$. Lower-than-average snow cover suited group hunting of fallow deer fawn $(-2.4 \mathrm{~cm})$ and fallow deer males $(-2.2 \mathrm{~cm})$. Sika deer fawn was hunted at the average snow cover margin. The standard error of the mean was rather large in mouflon males (SE 4.4), mouflon fawns (SE 3.0), fallow deer females (SE 1.3), mouflon females (SE 1.1), wild boar males (SE 1.0) and red deer males (SE 0.9).

A statistically significant difference in height of the snow cover was recorded in the case of individual hunting of fallow deer fawn and fallow deer male, similarly to the case of wild boar yearling and piglet. Different values were observed in red deer male, red deer fawn and red deer female. Values for red deer males and sika deer males are similar to those found in previous cases, as well as for fawns of both species. In the case of 
mouflon male and mouflon female, the values were also comparable, though significantly different from the mouflon fawn values.

In the case of group hunting, differences between red and sika deer adults and fawns were identified. There was no statistically significant difference between adult and young mouflons, similarly to the roe deer and fallow deer, or between the wild boar female, male and yearling, whose values, however, are statistically significantly different from piglet.

\section{Atmospheric pressure impact}

Fig. 9 shows average deviations from the atmospheric pressure in $\mathrm{hPa}$ on the hunting day by particular game species. Slightly over half of the game species (12) were hunted individually at higher-than-average atmospheric pressure, while the rest (10) at lowerthan-average pressure. Average atmospheric pressure was suitable for hunting mouflon females (1018 hPa, SE 1.44). Lower-than-average pressure was suitable especially for hunting fallow deer fawns $(-1.8 \mathrm{hPa})$, fallow deer females $(-1.3 \mathrm{hPa})$, roe deer females, sika deer females and wild boar males $(-0.8 \mathrm{hPa})$. The highest atmospheric pressure suited mouflon fawns $(3.4 \mathrm{hPa})$, fallow deer males $(2.5 \mathrm{hPa})$, sika deer males $(1.6 \mathrm{hPa})$, wild boar piglets $(1.0 \mathrm{hPa})$, red deer males $(0.9 \mathrm{hPa})$ and foxes $(0.7 \mathrm{hPa})$. A rather large SE was found in wild boar male (SE 2.3), mouflon fawn (SE 2.0), fallow deer fawn (SE 1.8), mouflon male (SE 1.7), fallow deer female, mouflon female (SE 1.4), wild boar female (SE 1.0) and European badger (SE 1.0).
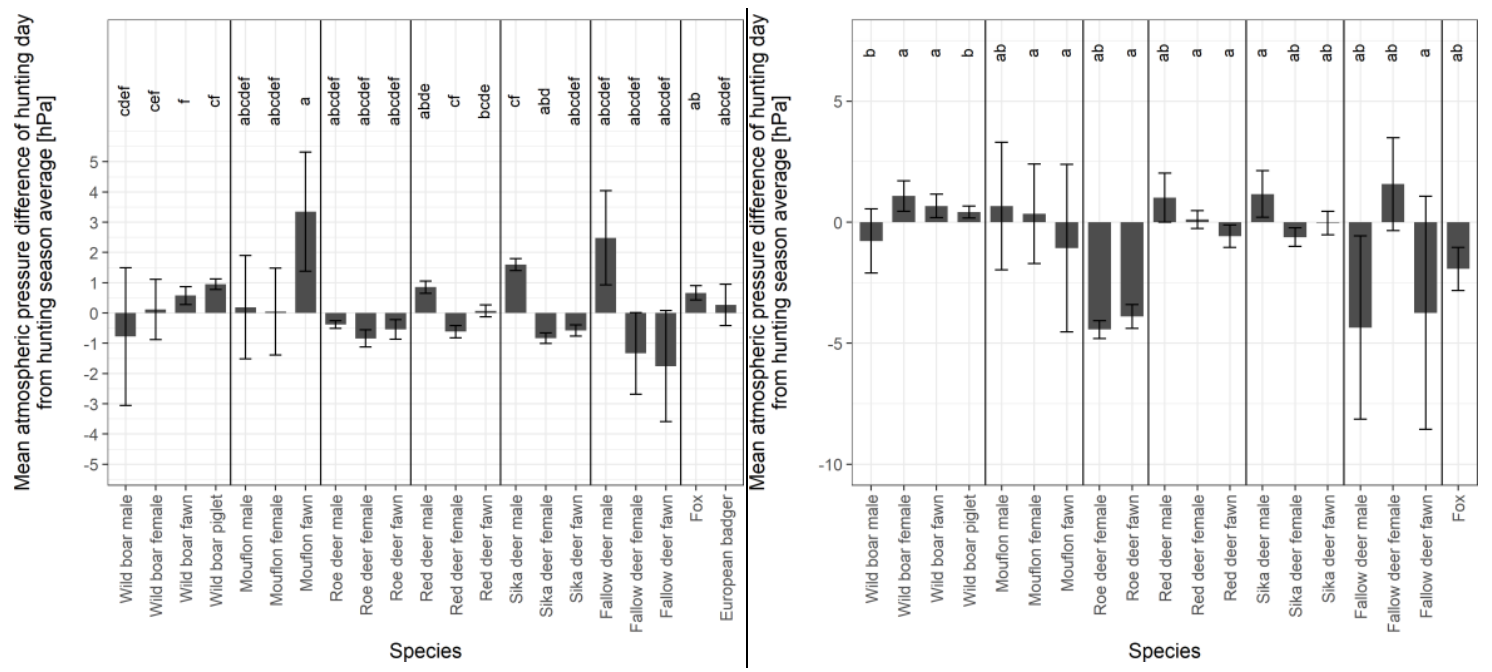

Figure 9. Mean deviations from the atmospheric pressure in hPa on the hunting day of individual hunting (left) and group hunting (right) by particular game species in 2005-2012; statistically significant differences among species are marked by different indices; error bars indicate standard error of the mean

Slightly over half of the game species (10) were group-hunted at lower-than-average atmospheric pressure, 2 species at average atmospheric pressure, and 8 species at higherthan-average atmospheric pressure. Average atmospheric pressure is suitable for hunting sika deer fawn and female (1018 hPa, SE 0.5 and 0.4). Lower-than-average pressure is suitable for hunting roe deer female, fallow deer male $(-4.4 \mathrm{hPa})$, roe deer fawn $(-3.9 \mathrm{hPa})$, fallow deer fawn $(-3.7 \mathrm{hPa})$. Higher-than-average atmospheric pressure suits grouphunting of fallow deer female $(1.6 \mathrm{hPa})$, sika deer male $(1.2 \mathrm{hPa})$, wild boar female 
$(1.1 \mathrm{hPa})$ and red deer male $(1.0 \mathrm{hPa})$. Very large SE was found in fallow deer fawn (SE 4.8), fallow deer male (SE 3.8), mouflon fawn (SE 3.5), mouflon female (SE 2.1), fallow deer female (SE 1.9); it was rather high in wild boar male (SE 1.3), red deer male and sika deer male (SE 1.0).

In the case of individual hunting, no statistically significant differences were identified in deviations from the average atmospheric pressure at the time of hunting between adult and juvenile fallow deer, roe deer or wild boar. Statistically significant differences were not detected even in the comparison of the females and fawns of both red and sika deer but significantly differed from the values of adult male deer. In the case of group hunting, there were no substantial differences between any of the game species mentioned.

\section{Interaction of climate and success of hunting}

The main part of data variability appeared to be caused by standardized values of temperature, which is an important parameter for both methods of hunting (Figs. 10 and 11). Standardized values of atmospheric pressure could be important as well, especially in the case of group hunting. Snow cover height is naturally negatively correlated with temperatures, similarly, negative correlation is observed between atmospheric pressure and precipitation. Increased variability in game hunting probability is observed when snow cover is present. In the case of individual method, roe deer male showed the lowest variability in relation to climatic factors in hunting days compared to high variability in mouflon fawn and wild board, where increasing atmospheric pressure, respectively snow cover had positive effect on success of hunting. Higher difference among game species was observed in the case of group hunting. For example, temperature had a positive effect on the success of hunting of European badger, respectively snow height on hunting of mouflon male.
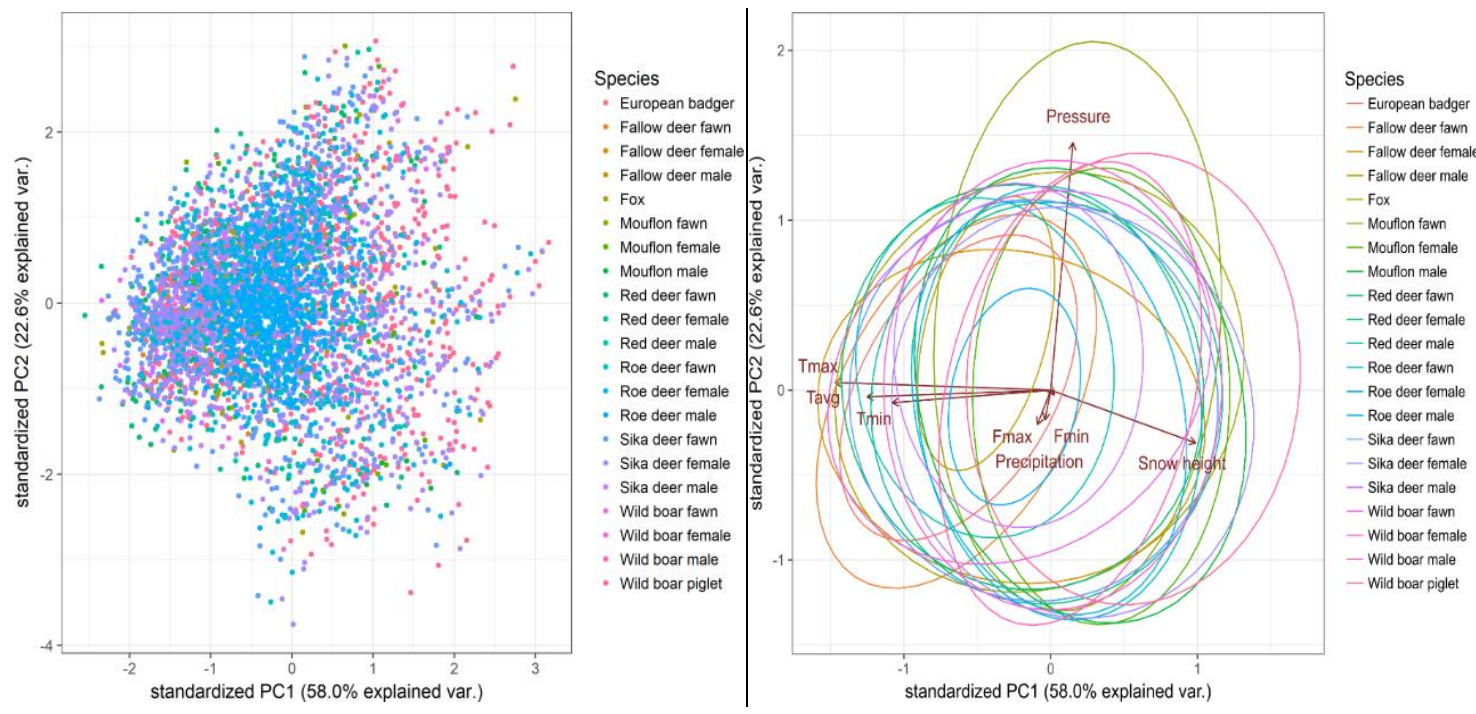

Figure 10. Analysis of the main components for standardized climatic data ( $F$ - minimum and maximum wind speed, $T$ - mean, minimum and maximum day time temperature, daily precipitation, daily snow cover, atmospheric pressure) for individual game species and respective individual hunting times - points (left) and ellipses of 50\% probability of occurrence (right) are displayed 


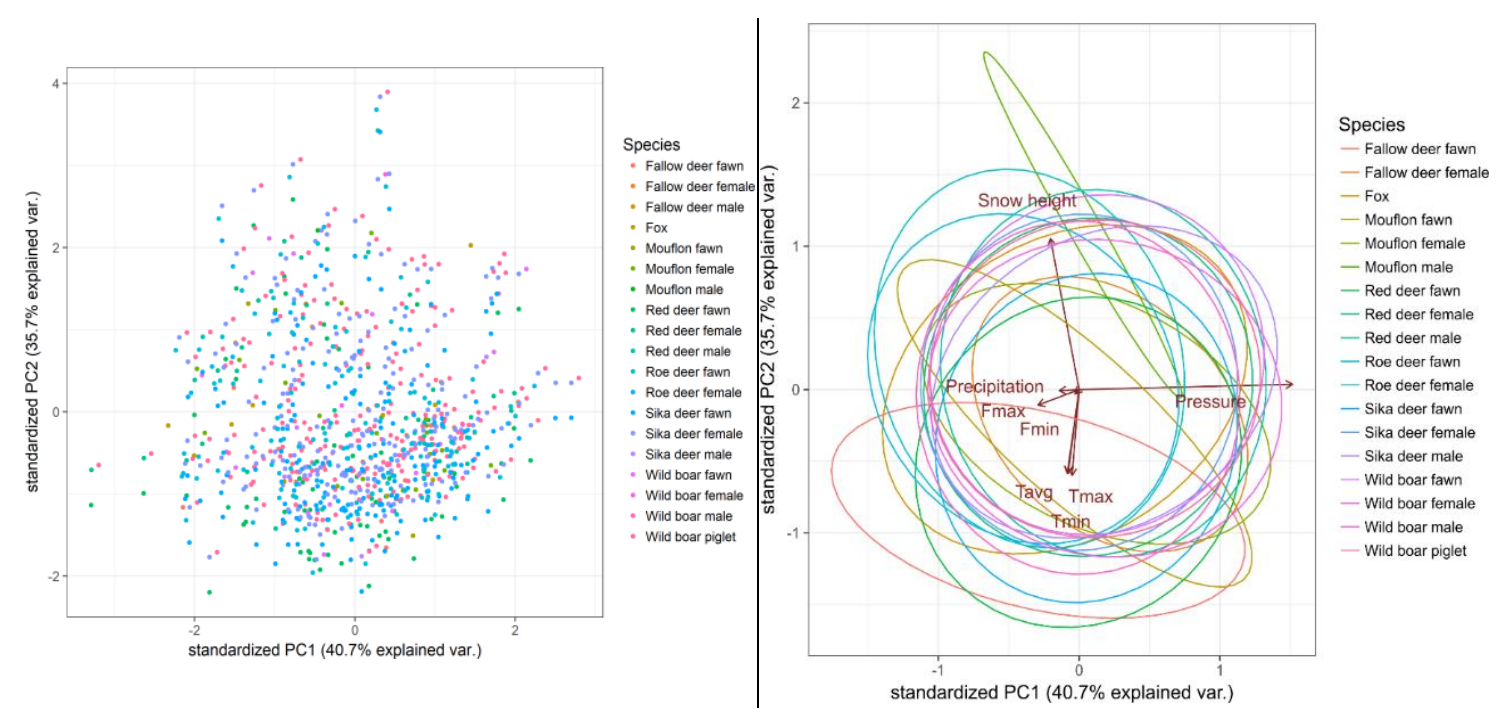

Figure 11. Analysis of the main components for standardized climatic data $(F-$ minimum and maximum wind speed, $T$ - mean, minimum and maximum day time temperature, daily precipitation, daily snow cover, atmospheric pressure) for individual game species and respective group hunting times - points (left) and ellipses of 50\% probability of occurrence (right) are displayed

Focusing on November and December (period with the highest number of hunted game), the success of hunting (both methods together) of all game species was increasing with increasing snow cover, increasing atmospheric pressure change and decreasing temperature, while there was no effect of precipitation. In individual hunting, the factors which had the highest effect on the success of hunting were: decreasing temperature, increasing snow cover and increasing atmospheric pressure change. The lowest effect was observed also in term of precipitation. In more detail in relation to deer species, the highest effect on the success of hunting was connected with decreasing temperature, while in wild boar it was increasing atmospheric pressure. In group hunting method, the highest positive effect on success of hunting was connected with decreasing temperature and increasing snow cover. Generally, lower effect of climate was observed in group hunting compared to individual hunting method.

\section{Discussion}

Numerous studies generally admit that climatic factors have a significant impact on forest game species populations and their dynamics. Borowik et al. (2013), for example, report that the climatic conditions (temperature, precipitation and snow cover) greatly influence the dynamics of ungulate populations by affecting the productivity of plants and, consequently, the energy requirements of ungulates (Saether, 1997; MartinezJauregui et al., 2009). Loison and Langvatn (1998) analysed the stock density of the red deer population in Norway and found that deep snow and high wind velocities correlated with low density of red deer. In the case of Polish red deer populations, the average January temperature negatively affected its population dynamics due to mortality in winter months (Okarma et al., 1995). Borowik et al. (2013) further confirmed the positive influence of increasing average temperature in January on the number of red deer in Poland. 
In our case, the assessment of temperature on the day of hunting of particular game species showed significant temperature fluctuations against an average value of the total hunting season for the given game species. In general, it is possible to observe - on the basis of the results found - that most game species are hunted at lower temperatures compared to the average at the time of hunting, especially in group hunting. However, this fact can be explained to some extent by the season of battues, which, most frequently, take place at the turn of the year, i.e. from November to January.

The influence of ambient temperature on ungulate populations has been verified and evaluated in relation to various habitat types used by the ungulates to relieve temperature stress (Merill, 1991; Mysterud and Østbye, 1995, 1999). The studies showed that high temperatures caused temperature stress, especially in the summer months, when the game seeks cover and is less active. Thus, the ungulates prefer habitats rich in cover and food, and significant reduction in their activity was observed (Godvik et al., 2009; Rivrud et al., 2014). Larger deer species are more susceptible to overheating (Mysterud and Østbye, 1999). An increase in the average temperature in January positively influenced the occurrence of roe deer in Poland (Borowik et al., 2013). Under unfavourable low temperature winter conditions, Holand et al. (1998) reported heavy leg strain, small body size and low chest height as factors hampering deer's survival. Okarma et al. (1995) in Poland and Kiili (1991) in Estonia found a relation between heavy frost, snow cover and the number of deer deaths from exhaustion, hunger and increased predatory pressure. In our research, analyses of numbers of hunted individuals confirmed that the assumption of a higher success rate was in lower-than-average temperature periods for particular game species. It was also confirmed inyear 2006, when winter temperature was extremely high $\left(+3.2^{\circ} \mathrm{C}\right.$ above average) with almost no snow and the smallest number of animals was hunted in this period.

Body heat losses due to precipitation were measured in white-tailed deer - with the resulting observation that heavier body heat losses were observed than in the case of lowtemperature-induced stress (Parker, 1988). Game seeks cover options to hide from furdampening, and thus reduces energy expenditure (Parker et al., 1984; Mysterud and Østbye, 1999). For these reasons, physical activity is minimized, and the game remains in the forest cover. It prefers mature forest habitats that provide more cover than young forest areas (König, 1987). A trend to hunt various game species in periods of less rainfall was also confirmed by our analyses. Fallow deer was hunted - both individually and in groups - on days of the lowest precipitation, both on group and on individual hunts. The original natural range of fallow deer is in Asia Minor and the Mediterranean (IUCN, 2018), i.e. in areas with lower precipitation totals compared to the Czech Republic. Another game species hunted in low-rainfall periods, is mouflon, which comes from the islands of Corsica and Sardinia and also from places of lower annual precipitation total (Schröder et al., 2016).

However, the native deer species are also hunted in periods of lower precipitation, which clearly confirms the theory of lower game activity on rainy days (Parker et al., 1984; König, 1987; Mysterud and Østbye, 1999). Low game activity reduces the chance for hunters to see it and successfully hunt it (Curtis, 1971). On the other hand, we can expect increased physical activity on days of lower-than-average rainfall from our results, which can be explained by the availability of good forage (Golodets et al., 2013; Lombardini et al., 2017). At the same time, the point of view of hunters also needs to be considered, as their effort to hunt and anticipation of worthwhile hunting experience on rainy days is reduced as well (Rivrud et al., 2014). However, to some extent, this fact can 
be ruled out in the case of the studied Hradiště hunting grounds in hunting female and young game as hunting is performed by forest and hunting management staff who are required to fulfil the hunting quota. The influence of increased snow cover on the number of deer is very well documented from other studies, for example, for the sika deer. In the second half of the $19^{\text {th }}$ century, Japanese islands witnessed a dramatic decline in sika deer numbers due to high snow cover, resulting in the banning of regulatory and commercial hunting (Kaji et al., 2000, 2010). On the other hand, the prediction for the development of sika deer numbers, which anticipates climate change and thus the reduction of snow cover, expects a significant increase in the population in the next decades (Ohashi et al., 2016).

Our direct assessment of the effect of the snow cover height on individual hunting success showed very varied values for particular game species. A dense canopy closure of forest stands reduces the height of snow cover; therefore, the game needs to emit less energy moving around the forest and finds fodder more easily (Mysterud and Østbye, 1999). However, in wild boar populations, Melis et al. (2006) indicate that deep snow and frozen soil significantly restrict their physical activity and ability to get food. Long and unfavourable winter conditions (low temperature at the beginning of spring) directly affected the survival rate of newborn wild boars in Switzerland (Geisser and Reyer, 2005). Okarma et al. (1995) in Poland and Kiili (1991) in Estonia found a correlation between high snow cover and the number of deer deaths caused by exhaustion.

Therefore, it appears that the success rate of hunting in the case of snow cover depends on the behaviour and nutritional requirements of the particular game species. In wild boar, for example, hunting from hides is considered the most effective as it takes only 18 man-hours to hunt an animal (Keuling et al., 2008). Efficiency of hunting from hides can be increased by sharpshooting at bait (Doerr et al., 2001). This method is popular in the Czech Republic especially for wild boar hunting in seasons of natural food deficiency. That explains, for example, a higher success rate of hunting piglets on days with higherthan-average snow cover in our study. Higher success rate of battues can probably be explained by the term they are organized, i.e. especially in winter months. Generally, most of the game is hunted in the winter months, while in our study we focused in particular on November and December (such as in other studies - Cupples and Jackson, 2014), when on average over $54 \%$ of the total number of animals was hunted during the year in the Doupov Hills. Our results showed that success of hunting of game species was increasing with increasing snow cover, increasing atmospheric pressure change and decreasing temperature.

The fluctuation of atmospheric pressure explains a large part of annual variability of temperatures and precipitation in Northern Europe (Hurrell, 1995). High pressure combined with high temperature and sufficient precipitation at nesting time had a beneficial effect on the reproduction of snow goose (Chen caerulescens atlantica Kennard) (Dickey et al., 2008). Atmospheric pressure, together with temperature and precipitation, are the most important variables in relation to weather conditions and also in relation to living organisms (Hawkins and Klimstra, 1970; Knape and de Valpine, 2010). Rapid changes in atmospheric pressure influence the animal-activity patterns (Ables, 1969; Bender and Hartman, 2015) and it can significantly affect the success of the hunting. Hynes (2014) documented that the best hunting time of white-tailed deer is when the pressure is changing, especially when the pressure immediately increases. Our study confirmed the effect of positive atmospheric pressure effect on the success of hunting, especially in individual hunting method and in wild boar. Slightly over a half of 
game species are hunted at a lower-than-average atmospheric pressure in the the Doupov Hills. Also, in our case, a negative correlation between atmospheric pressure and precipitation was found. A comparison of the atmospheric pressure on the day of hunting showed no statistically significant differences between females and fawns of the two deer species, but they did differ significantly from the values for adult males.

Long-term influence of weather during the vegetation season is also indisputable, as it affects the quality and quantity of natural food (Albon and Langvatn, 1992; Solberg et al., 1999). It can be documented, for example, in the wild boar. The number of wild boar piglets was positively influenced by higher temperatures and higher precipitation in summer, as well as by the higher yield of acorns (Frauendofr et al., 2016) which is, together with beech nuts, the most important source of natural food (Jȩdrzejewska et al., $1994,1997)$ and its yield is also very closely related to climatic influences. The success of the hunt is therefore indirectly influenced by the climate-supported higher numbers of game. The hunter is then more likely to see the game and successfully hunt it.

Borowik et al. (2013) report that, as part of the ongoing changes that are directly related to global warming, ever-milder winter conditions improve the lives of ungulates in Central Europe, leading to their increased numbers. In addition, rising temperatures cause changes in the utilization of the ungulates' habitats. In recent decades, a shift in phenology and tree composition has been observed, with coniferous stands being gradually replaced by mixed and deciduous forests (Sykes et al., 1996; Root et al., 2003; Hanewinkel et al., 2013), increasing the carrying capacity of hunting grounds (Gallo and Pejchar, 2016).

\section{Conclusion}

The success of game hunting depends on many factors that can be influenced to a certain extent, improving hunting success significantly. Hunters are supposed, for example, to be familiar with the hunting grounds, with biology of the game and its habitats, and should be able to choose suitable hunting and method (individual or group). There are more factors beyond the hunters' will. Among the most notable unavoidable factors influencing hunting activities are undoubtedly the weather patterns at a given time and place, e.g. air temperature, atmospheric pressure, precipitation, wind speed and snow cover height on the hunting day. In the Doupov Hills, it was the air temperature on the hunting day that had the greatest impact on hunting success. In the case of the snow cover, an increased variability in the values of the studied climatic parameters was observed on the day of hunting. Atmospheric pressure, together with temperature, was one of the most important variables in relation to weather conditions and to living organisms, substantially influencing their physiological processes and well-being and hence the success of hunting. Results showed that the success of hunting was increasing with decreasing air temperature, increasing snow cover and increasing atmospheric pressure change, especially in the case of individual hunting method. On the other hand, precipitation and wind speed had relatively low effect on the success of hunting. Individual hunting was associated with significantly better climatic conditions in comparison to group hunting, such as in the case of hunting of male game species compared to female. However, in relation to the success of the hunting, it is also necessary to focus on other factors not analysed in this study, for example habitat conditions, time of hunting, food source, air humidity, sunshine (clouds), wind direction, fog etc. The findings of this study can contribute to future research and planning of suitable times and methods of hunting and thus supporting successful hunting in montane and submontane regions of Central Europe. 
Acknowledgements. This study was supported by the Czech University of Life Sciences Prague, Faculty of Environmental Sciences (No. IGA B13/14) and Faculty of Forestry and Wood Sciences. We are grateful to two anonymous reviewers and editor for their constructive comments and valuable suggestions that helped improve the manuscript.

\section{REFERENCES}

[1] Ables, E. D. (1969): Activity studies of Red Foxes in southern Wisconsin. - Journal of Wildlife Management 33: 145-153.

[2] Albon, S. D., Langvatn, R. (1992): Plant phenology and the benefits of migration in a temperate ungulate. - Oikos 65: 502-513.

[3] Ambrož, R., Vacek, S., Vacek, Z., Král, J., Štefančík, I. (2015): Current and simulated structure, growth parameters and regeneration of beech forests with different game management in the Lány Game Enclosure. - Central European Forestry Journal 61(2): 7888.

[4] Balmford, A., Green, R. E., Jenkins, M. (2003): Measuring the changing state of nature.Trends in Ecology \& Evolution 18: 326-330.

[5] Baltzinger, M., Mårell, A., Archaux, F., Pérot, T., Leterme, F., Deconchat, M. (2016): Overabundant ungulates in French Sologne? Increasing red deer and wild boar pressure may not threaten woodland birds in mature forest stands. - Basic and Applied Ecology 17(6): 552-563.

[6] Bender, M. J., Hartman, G. D. (2015): Bat activity increases with barometric pressure and temperature during autumn in central Georgia. - Southeastern naturalist 14(2): 231-243.

[7] Bischof, R., Nilsen, E. B., Brøseth, H., Männil, P., Ozoliņš, J., Linnell, J. D. C. (2012): Implementation uncertainty when using recreational hunting to manage carnivores. Journal of Applied Ecology 49(4): 824-832.

[8] Bleier, N., Lehoczki, R., Úváry, D., Szemethy, L., Csányi, S. (2012): Relationship between wild ungulates density and crop damage in Hungary. - Acta Theriologica 57(4): 351-359.

[9] Böhning-Gaesa, K., Lemoine, N. (2004): Importance of climate change for the ranges, communities and conservation of birds. - Advances in Ecological Research 35: 211-236.

[10] Borowik, T., Cornulier, T., Jędrzejewska, B. (2013): Environmental factors shaping ungulate abundances in Poland. - Acta Theriologica 58: 403-413.

[11] Buckland, S. T., Ahmadi, S., Staines, B. W., Gordons, I. J., Youngson, R. W. (1996): Estimating the minimum population size that allows a given annual number of mature red deer stags to be culled sustainably. - Journal of Applied Ecology 33: 118-130.

[12] Bunnefeld, N., Baines, D., Newborn, D., Milner-Gulland, E. J. (2009): Factors affecting unintentional harvesting selectivity in a monomorphic species. - Journal of Animal Ecology 78: 485-492.

[13] Ciuti, S., Muhly, T. B., Paton, D. G., McDevitt, D., Musiani, M., Boyce, M. S. (2012): Human selection of elk behavioural traits in a landscape of fear. - Proceedings of the Royal Society B: Biological Sciences 279: 4407-4416.

[14] Conner, S. R., Lee, J. T., Carey, J., Bailey, C. A. (2001): Nutrient characterization of guar meal fractions. - Poultry Science 80(1): 50.

[15] Coulson, T. E., Catchpole, A., Albon, S. D., Morgan, B. J. T., Pemberton, J. M., CluttonBrock, T. H., Crawley, M. J., Grenfell, B. T. (2001): Age, sex, density, winter weather, and population crashes in Soay sheep. - Science 292: 1528-1531.

[16] Cukor, J., Vacek, Z., Linda, R., Remeš, J., Bílek, L., Sharma, R. P., Baláš, M., Kupka, I. (2017): Effect of mineral eco-fertilizer on growth and mortality of young afforestations. Austrian Journal of Forest Science 134(4): 367-385.

[17] Cukor, J., Havránek, F., Vacek, Z., Bukovjan, K., Podrázský, V., Sharma, R. P. (2019a): Roe deer (Capreolus capreolus) mortality in relation to fodder harvest in agricultural landscape. - Mammalia 83(5): 461-469. 
[18] Cukor, J., Vacek, Z., Linda, R., Sharma, R. P., Vacek, S. (2019b): Afforested farmland vs. forestland: Effects of bark stripping by Cervus elaphus and climate on production potential and structure of Picea abies forests. - PloS one 14(8): e0221082.

[19] Cukor, J., Vacek, Z., Linda, R., Vacek, S., Marada, P., Šimůnek, V., Havránek, F. (2019c): Effects of bark stripping on timber production and structure of Norway spruce forests in relation to climatic factors. - Forests 10(4): 320.

[20] Cukor, J., Bartoška, J., Rohla, J., Sova, J., Machálek, A. (2019d): Use of aerial thermography to reduce mortality of roe deer fawns before harvest. - PeerJ 7: e6923.

[21] Culek, M., Grulich, V., Laštůvka, Z., Diviššek, J. (2013): Biogeografické regiony České republiky. - Masarykova univerzita, Brno.

[22] Cupples, J. B., Jackson, D. H. (2014): Comparison of mule deer distributions during winter and hunting seasons in south-central Oregon. - Department of Fish and Wildlife, Oregon.

[23] Curtis, R. L. J. (1971): Climatic factors influencing hunter sightings of red deer on the broad run research area. - Virginia Polytech Institute, Blacksburg, VA.

[24] Demek, J., Mackovčin, P. (eds.) (2006): Zeměpisný lexikon ČR - Hory a nížiny. - Agentura ochrany prírody ČR, Brno.

[25] Dickey, M. H., Gauthier, G., Cadieux, M. C. (2008): Climatic effects on the breeding phenology and reproductive success of an arctic-nesting goose species. - Global Change Biology 14: 1973-1985.

[26] Doerr, M. L., McAninch, J. B., Wiggers, E. P. (2001): Comparison of four methods to reduce white-tailed deer abundance in an urban community. - Wildlife Society Bulletin 29: 1105-1113.

[27] Forchhammer, M. C., Stenseth, N. C., Post, E., Langvatn, R. (1998): Population dynamics of Norwegian red deer: densitydependence and climatic variation. - Proceedings of the Royal Society B: Biological Sciences 265: 341-350.

[28] Forsman, J. T., Mönkkönen, M. (2003): The role of climate in limiting European resident bird populations. - Journal of Biogeography 30: 55-70.

[29] Frauendorf, M., Gethöffer, F., Siebert, U., Keuling, O. (2016): The influence of environmental and physiological factors on the litter size of wild boar (Sus scrofa) in an agriculture dominated area in Germany. - Science of the Total Environment 541: 877-882.

[30] Gaillard, J. M., Delorme, D., Boutin, J. M., Vanlaere, G., Boisaubert, B., Pradel, R. (1993): Roe deer survival patterns - a comparative analysis of contrasting populations. - Journal of Animal Ecology 62: 778-791.

[31] Gallo, T., Pejchar, L. (2016): Improving habitat for game animals has mixed consequences for biodiversity conservation. - Biological Conservation 197: 4752.

[32] Geisser, H., Reyer, H. U. (2005): The influence of food and temperature on population density of wild boar Sus scrofa in the Thurgau (Switzerland). - Journal of Zoology 267: 89-96.

[33] Gerhardt, P., Arnold, J. M., Hacklander, K., Hochbichler, E. (2013): Determinants of deer impact in European forests - A systematic literature analysis. - Forest Ecology and Management 310: 173-186.

[34] Godvik, I. M. R., Loe, L. E., Vik, J. O., Veiberg, V., Langvatn, R., Mysterud, A. (2009): Temporal scales, trade-offs, and functional responses in red deer habitat selection. Ecology 90: 699-710.

[35] Golodets, C., Sternberg, M., Kigel, J., Boeken, B., Henkin, Z., Seligman, N. G., Ungar, E. D. (2013): From desert to Mediiterranean rangelands: will increasing drough and interannual rainfall variability affect herbaceous annual primary productivity? - Climatic Change 119(3-4): 785-798.

[36] Hagen, R., Heurich, M., Kröschel, M., Herdtfelder, M. (2014): Synchrony in hunting bags: Reaction on climatic and human induced changes? - Science of the Total Environment 468-469: 140-146. 
[37] Hallett, T. B., Coulson, T., Pilkington, J. G., Clutton-Brock, T. H., Pemberton, J. M., Grenfell, B. T. (2004): Why largescale climatic indices seem to predict ecological processes better than local weather. - Nature 430: 71-75.

[38] Hanewinkel, M., Cullmann, D. A., Schelhaas, M. J., Nabuurs, G. J., Zimmermann, N. E. (2013): Climate change may cause severe loss in the economic value of European forest land. - Nature Climatic Change 3: 203-207.

[39] Hawkins, R. E., Klimstra, W. D. (1970): Deer trapping correlated with weather factors. Transactions of the Illinois State Academy of Science 63(2): 198-201.

[40] Hays, G. C., Richardson, A. J., Robinson, C. (2005): Climate chase and marine plankton. - Trends in Ecology \& Evolution 20: 337-344.

[41] Hegel, T. M., Mysterud, A., Huettmann, F., Stenseth, N. C. (2010): Interacting effect of wolves and climate on recruitment in a northern mountain caribou population. - Oikos 119: 1453-1461.

[42] Herrero, J., Garcia-Serrano, A., Couto, S., Ortuno, V., Garcia-Gonzalez, R. (2006): Diet of wild boar Sus scrofa L. and crop damage in an intensive agroecosystem. - European Journal of Wildlife Research 52: 245-250.

[43] Heurich, M., Möst, L., Schauberger, G., Reulen, H., Sustr, P., Hothorn, T. (2012): Survival and causes of death of European Roe Deer before and after Eurasian Lynx reintroduction in the Bavarian Forest National Park. - European Journal of Wildlife Research 58: 567578.

[44] Heurich, M., Brand, T. T. G., Kaandorp, M. Y., Sustr, P., Muller, J., Reineking, B. (2015): Country, Cover and Protection: What Shapes the Distribution of Red Deer and Roe Deer in the Bohemian Forest Ecosystem? - PloS One 10(3): 1-17.

[45] Holand, Ø., Mysterud, A., Wannag, A., Linnell, J. D. C. (1998): Roe deer in northern environments: physiology and behavior. - In: Andersen, R., Duncan, P., Linnell, J. D. C. (eds.) The European roe deer: the biology of success. Scandinavian University Press, Oslo..

[46] Hone, J., Clutton-Brock, T. H. (2007): Climate, food, density and wildlife population growth rate. - Journal of Animal Ecology 76: 361-367.

[47] Hothorn, T., Müller, J. (2010): Large-scale reduction of ungulate browsing by managed sport hunting. - Forest Ecology and Management 260: 1416-1423.

[48] Hurrell, J. W. (1995): Decadal trends in the North Atlantic oscillation: Regional temperatures and precipitation. - Science 269: 676-679.

[49] Hynes, R. (2014): Whitetail Movement and Barometric Pressure. - 365 Whitetail.

[50] IUCN (International Union for Conservation of Nature) (2018): The IUCN Red List of Threatened Species. - Available at: http://maps.iucnredlist.org/ (verified July 2018).

[51] Jędrzejewska, B., Okarma, H., Jędrzejewski, W., Miłkowski, L. (1994): Effects of exploitation and protection on forest structure, ungulate density and wolf predation in Białowieża Primeval Forest, Poland. - Journal of Applied Ecology 31: 664-676.

[52] Jędrzejewska, B., Jędrzejewski, W., Bunevich, A. N., Milkowski, L., Krasinski, Z. A. (1997): Factors shaping population densities and increase rates of ungulates in Białowieża Primeval Forest (Poland and Belarus) in the 19th and 20th centuries. - Acta Theriologica 42: 399-451.

[53] Johnson, J. B., Omland, K. S. (2004): Model selection in ecology and evolution. - Trends in Ecology \& Evolution 19: 101-108.

[54] Kaji, K., Miyaki, M., Saitoh, T., Ono, S., Kaneko, M. (2000): Spatial Distribution of an Expanding Sika Deer Population on Hokkaido Island, Japan. - Wildlife Society Bulletin 28: 699-707.

[55] Kaji, K., Saitoh, T., Uno, H., Matsuda, H., Yamamura, K. (2010): Adaptive management of sika deer populations in Hokkaido, Japan: theory and practice. - Population Ecology 52: 373-387.

[56] Kamei, T., Takeda, K., Izumiyama, S., Ohshima, K. (2010): The Effect of Hunting on the Behavior and Habitat Utilization of Sika Deer (Cervus nippon). - Mammal Study 35: 235241. 
[57] Keuling, O., Stier, N., Roth, M. (2008): How does hunting influence activity and space use in wild boar Sus scrofa. - European Journal of Wildlife Research 54: 729-737.

[58] Keuling, O., Baubet, E., Duscher, A., Ebert, C., Fischer, C., Monaco, A., Podgórski, T., Prevot, C., Ronnenbert, K., Sodeikat, G., Stier, N., Thurfjell, H. (2013): Mortality rates of wild boar Sus scrofa L. in central Europe. - European Journal of Wildlife Research 59: 805-814.

[59] Kiili, J. (1991): Influences of climatic factors on roe deer population dynamics in Estonia. - In: Bobek, B., Regelin, W. (eds.) Global trends in wildlife management, transactions 18th IUGB Congress, Kraków 1987. Świat Press, Kraków-Warszawa.

[60] Knape, J., de Valpine, P. (2010): Effects of weather and climate on the dynamics of animal population time series. - Proceedings of the Royal Society B: Biological Sciences 278(1708): 985-992.

[61] König, K. P. (1987): Territory-holding over time by roe deer in closed woodland areas. Zeitschrift für Jagdwissenschaft 33: 168-175.

[62] Koons, D. N., Colchero, F., Hersey, K., Gimenez, O. (2015): Disentangling the effects of climate, density dependence, and harvest on an iconic large herbivore's population dynamics. - Ecological Applications 25(4): 956-967.

[63] Köppen, W. P. (1936): Das Geographische System der Klimate. - In: Köppen, W., Geiger, R. (eds.) Handbuch der Klimatologie. Gebrüder Bornträger, Berlin.

[64] Kuijper, D. P. J., de Kleine, C., Churski, M., van Hooft, P., Bubnicki, J., Jędrzejewska, B. (2013): Landscape of fear in Europe: wolves affect spatial patterns of ungulate browsing in Białowieża Primeval Forest, Poland. - Ecography 36(12): 1263-1275.

[65] Kunkel, K. E., Pletscher, D. H. (2000): Habitat factors affecting vulnerability of moose to predation by wolves in southeastern British Columbia. - Canadian Journal of Zoology 78: $150-157$.

[66] Langvatn, R., Albon, S. D., Burkey, T., Clutton-Brock, T. H. (1996): Climate, plant phenology and variation in age of first reproduction in a temperate herbivore. - Journal of Animal Ecology 65: 653-670.

[67] Lebel, F., Dussault, C., Massé, A., Côte, S. D. (2012): Influence of habitat features and hunter behavior on white-tailed deer harvest. - Journal of Wildlife Management 76: 14311440 .

[68] Levers, C., Butsic, V., Verburg, P. H., Muller, D., Kuemmerle, T. (2016): Drivers of changes in agricultural intensity in Europe. - Land Use Policy 58: 380-393.

[69] Linchant, J., Lisein, J., Semeki, J., Lejeune, P., Vermeulen, C. (2015): Are unmanned aircraft systems (UAS s) the future of wildlife monitoring? A review of accomplishments and challenges. - Mammal Review 45(4): 239-252.

[70] Loison, A., Langvatn, R. (1998): Short- and long-term effects of winter and spring weather on growth and survival of red deer in Norway. - Oecologia 116: 489-500.

[71] Lombardini, M., Varuzza, P., Meriggi, A. (2017): Influence of weather and phenotypic characteristics on pregnancy rates of female roe deer in central Italy. - Population Ecology 59: 131-137.

[72] Lundmark, H., Josefsson, T., Östlund, L. (2013): The history of clear-cutting in northern Sweden-driving forces and myths in boreal silviculture. - Forest Ecology and Management 307: 112-122.

[73] Månsson, J., Jarnemo, A. (2013): Bark-stripping on Norway spruce by red deer in Sweden: level of damage and relation to tree characteristics. - Scandinavian Journal of Forest Research 28(2): 117-125.

[74] Marada, P., Cukor, J., Linda, R., Vacek, Z., Vacek, S., Havránek, F. (2019): Extensive Orchards in the Agricultural Landscape: Effective Protection against Fraying Damage Caused by Roe Deer. - Sustainability 11(13): 3738.

[75] Martinez-Jauregui, M., San Miguel-Ayanz, A., Mysterud, A., Rodriguez-Vigal, C., Clutton-Brock, T. H., Langvatn, R., Coulson, T. (2009): Are local weather, NDVI and 
NAO consistent determinants of red deer weight across three contrasting European countries? - Global Change Biology 15: 1727-1738.

[76] Matějů, J., Hradecký, P., Melichar, V. (2016): Doupovské hory. - Česká geologická služba, Praha.

[77] Melis, C., Szafrańska, P. A., Jędrzejewska, B., Bartoń, K. (2006): Biogeographical variation in the population density of wild boar (Sus scrofa) in western Eurasia. - Journal of Biogeography 33: 803-811.

[78] Merill, E. H. (1991): Thermal constraints on use of cover types and activity time of elk. Applied Animal Behaviour Science 29: 251-267.

[79] Merkel, F. R. (2010): Evidence of recent population recovery in common eiders breeding in Western Greenland. - Journal of Wildlife Management 74: 1869-1874.

[80] Millspaugh, J. J., Coleman, M. A., Bauman, B. J., Raedeke, K. J., Brundige, G. C. (2000): Serum profiles of American elk at the time of handling for three capture methods. Canadian Field-Naturalist 114: 196-200.

[81] Milner, J. M., Elston, D. A., Albon, S. D. (1999): Estimating the contributions of population density and climatic fluctuations to interannual variation in survival of Soay sheep. Journal of Animal Ecology 68: 1235-1247.

[82] Mower, K. J., Townsend, T. W., Tyznik, W. J. (1997): White-tailed deer damage to experimental apple orchards in Ohio. - Wildlife Society Bulletin 25(2): 337-343.

[83] Mysterud, A., Østbye, E. (1995): Bed-site selection by European roe deer (Capreolus capreolus) in southern Norway during winter. - Canadian Journal of Zoology 73: 924-932.

[84] Mysterud, A., Østbye, E. (1999): Cover as a habitat element for temperate ungulates: effects on habitat selection and demography. - Wildlife Society Bulletin 27: 385-394.

[85] Newton, I. (1998): Population limitation in birds. - Academic Press, London, U.K.

[86] Nilsen, E. B., Gaillard, J. M., Andersen, R., Odden, J., Delorme, D., van Laere, G., Linnell, J. D. C. (2009): A slow life in hell or a fast life in heaven: demographic analyses of contrasting roe deer populations. - Journal of Animal Ecology 78: 585-594.

[87] Nugent, G., Choquenot, D. (2004): Comparing cost-effectiveness of commercial harvesting, state-funded culling, and recreational deer hunting in New Zealand. - Wildlife Society Bulletin 32: 481-492.

[88] Ohashi, H., Kominami, Y., Higa, M., Koide, D., Nakao, K., Tsuyama, I., Matsui, T., Tanaka, N. (2016): Land abandonment and changes in snow cower period accelerate range expansion of sika deer. - Ecology and Evolution 6: 7763-7775.

[89] Okarma, H., Jędrzejewska, B., Jędrzejewski, W., Krasiński, Z. A., Miłkowski, L. (1995): The roles of predation, snow cover, acorn crop, and man-related factors on ungulate mortality in Białowieża Primeval Forest, Poland. - Acta Theriologica 40: 197-217.

[90] Parker, K. L., Robbins, C. T., Hanley, T. A. (1984): Energy expenditures for locomotion by mule deer and elk. - Journal of Wildlife Management 48: 474-488.

[91] Parker, K. L. (1988): Effects of heat, cold, and rain on coastal black-tailed deer. - Canadian Journal of Zoology 66: 2475-2483.

[92] Parmesan, C. (2006): Ecological and evolutionary responses to recent climate change. Annual Review of Ecology, Evolution, and Systematics 37: 637-669.

[93] Peñuelas, J., Filella, I., Comas, P. (2002): Changed plant and animal life cycles from 1952 to 2000 in the Mediterranean region. - Global Change Biology 8: 531-544.

[94] Pérez-Espona, S., Pemberton, J. M., Putman, R. (2009): Red and sika deer in the British Isles, current management issues and management policy. - Mammalian Biology 79: 247262.

[95] Pettorelli, N., Pelletier, F., von Hardenberg, A., Festa-Bianchet, M., Cote, S. D. (2007): Early onset of vegetation growth vs rapid green-up: impacts on juvenile mountain ungulates. - Ecology 88: 381-390.

[96] Pitra, C., Lutz, W. (2005): Population genetic structure and the effect of founder events on the genetic variability of introduced sika deer, Cervus nippon, in Germany and Austria. European Journal of Wildlife Research 51: 95-100. 
[97] Plíva, K., Žlábek, I. (1986): Přírodní lesní oblasti ČSR. - SZN, Prague.

[98] Pohja-Mykrä, M., Vuorisalo, T., Mykrä, S. (2005): Hunting bounties as a key measure of historical wildlife management and game conservation: Finnish bounty schemes 16471975. - Oryx 39(3): 284-291.

[99] Post, E., Stenseth, N. C. (1999): Climatic variability, plant phenology, and northern ungulates. - Ecology 80: 1322-1339.

[100] Průša, E. (2001): Pěstování lesů na typologických základech. - Lesnická práce, s. r. o., Kostelec nad Černými lesy.

[101] Putman, R. J., Moore, N. P. (1998): Impact of deer in lowland Britain on agriculture, forestry and conservation habitats. - Mammal Review 28: 141-164

[102] Quirós-Fernández, F., Marcos, J., Acevedo, P., Gortázar, C. (2017): Hunters serving the ecosystem: the contribution of recreational hunting to wild boar population control. European Journal of Wildlife Research 63(3): 57.

[103] R Core Team (2018): R: A language and environment for statistical computing. - R Foundation for Statistical Computing, Vienna, Austria. URL https://www.R-project.org/.

[104] Ramankutty, N., Foley, J. A. (1999): Estimating historical changes in global land cover: Croplands from 1700 to 1992. - Global Biogeochemical Cycles 13(4): 997-1027.

[105] Rivrud, I. M., Loe, L. E., Mysterud, A. (2010): How does local weather predict red deer home range size at different temporal scales? - Journal of Animal Ecology 79: 1280-1295.

[106] Rivrud, I. M., Sonkoly, K., Lehoczki, R., Csányi, S., Storvik, G. O., Mysterud, A. (2013): Hunter selection and long-term trend (1881-2008) of red deer trophy sizes in Hungary. Journal of Applied Ecology 50(1): 168-180.

[107] Rivrud, I. M., Meisingset, E., Loe, L. E., Mysterud, A. (2014): Interaction effects between weather and space use on harvesting effort and patterns in red deer. - Ecology and Evolution 4(24): 2045-7758.

[108] Root, B. G., Fritzell, E. K., Giessman, N. F. (1988): Effects of intensive hunting on whitetailed deer movement. - Wildlife Society Bulletin 16(2): 145-151.

[109] Saether, B. E. (1997): Environmental stochasticity and population dynamics of large herbivores: a search for mechanisms. - Trends in Ecology \& Evolution 12: 143-149.

[110] Sauerbrei, R., Ekschmitt, K., Wolters, V., Gottschalk, T. (2014): Increased Energy maize production reduces farmland bird diversity. - Global Change Biology Bioenergy 6(3): 265274.

[111] Schröder, O., Lieckfeldt, D., Lutz, W., Rudloff, C., Frölich, K., Ludwig, A. (2016): Limited hybridization between domestic sheep and the European mouflon in Western Germany. European Journal of Wildlife Research 62: 307-314.

[112] Simard, M. A., Coulson, T., Gingras, A., Cote, S. D. (2010): Influence of density and climate on population dynamics of a large herbivore under harsh environmental conditions. - Journal of Wildlife Management 74: 1671-1685.

[113] Sims, M., Elston, D. A., Larkham, A., Nussey, D. H., Albon, S. D. (2007): Identifying when weather influences life-history traits of grazing herbivores. - Journal of Animal Ecology 76: 761-770.

[114] Slanař, J., Vacek, Z., Vacek, S., Bulušek, D., Cukor, J., Štefančík, I., Bílek, L., Král, J. (2017): Long-term transformation of submontane spruce-beech forests in the Jizerské hory Mts.: dynamics of natural regeneration. - Central European Forestry Journal 63(4): 213225.

[115] Solberg, E. J., Saether, B. E., Strand, O., Loison, A. (1999): Dynamics of a harvested moose population in a variable environment. - Journal of Animal Ecology 68: 186-204.

[116] Solberg, E. J., Rolandsen, C. M., Heim, M., Linnell, J. D. C., Herfindal, I., Sæther, B. E. (2010): Age and sex-specific variation in detectability of moose (Alces alces) during the hunting season: implications for population monitoring. - European Journal of Wildlife Research 56: 871-881. 
[117] Sykes, M. T., Prentice, I. C., Cramer, W. (1996): A bioclimatic model for the potential distributions of north European tree species under present and future climates. - Journal of Biogeography 23: 203-233.

[118] Theuerkauf, J., Jedrzejewski, W., Schmidt, K., Okarma, H., Ruczynski, I., Sniezko, S., Gula, R. (2003): Daily patterns and duration of wolf activity in the Bialowieza Forest, Poland. - Journal of Mammalogy 84: 243-253.

[119] Thomas, C. D., Cameron, A., Green, R. E., Bakkenes, M., Beaumont, L., Collingham, Y., Erasmus, B. F., De Siqueira, M. F., Grainger, A., Hannah, L., Hughes, L., Huntley, B., Van Jaarsveld, A. S., Midgley, G. F., Miles, L., Ortega-Huerta, M. A., Peterson, A. T., Phillips, O. L., Williams, S. E. (2004): Extinction risk from climate change. - Nature 427: 145-148.

[120] Thomas, C. D., Franco, A. M. A., Hill, J. K. (2006): Range retractions and extinction in the face of climate warming. - Trends in Ecology \& Evolution 21: 415-416.

[121] Thulin, C. G., Malmsten, J., Ericsson, G. (2015): Opportunities and challenges with growing wildlife populations and zoonotic diseases in Sweden. - European Journal of Wildlife Research 61(5): 649-656.

[122] Tolasz, R., Míková, T., Valeriánová, A., Voženílek, V. (eds.) (2007): Climatic Atlas of Czechia. - ČHMÚ, Prague.

[123] Tscharntke, T., Klein, A. M., Kruess, A., Steffan-Dewenter, I., Thies, C. (2005): Landscape perspectives on agricultural intensification and biodiversity-ecosystem service management. - Ecology letters 8(8): 857-874.

[124] Tuyttens, F. A. M., Macdonald, D. W. (2000): Social perturbation: consequences for wildlife management and conservation. - Behaviour and conservation, Cambridge University Press, Cambridge, United Kingdom.

[125] Vacek, S., Vančura, K., Zingari, P. C., Jeník, J., Simon, J., Smejkal, J. (2003): Mountain forests of the Czech Republic. - Ministry of Agriculture, Prague.

[126] Vacek, Z., Vacek, S., Bílek, L., Král, J., Remeš, J., Bulušek, D., Králíček, I. (2014): Ungulate Impact on Natural Regeneration in Spruce-Beech-Fir Stands in Černý důl Nature Reserve in the Orlické Hory Mountains, Case Study from Central Sudetes. - Forests 5: 2929-2946.

[127] Vacek, S., Vacek, Z., Bulušek, D., Bílek, L., Schwarz, O., Simon, J., Štícha, V. (2015): The role of shelterwood cutting and protection against game browsing for the regeneration of silver fir. - Austrian Journal of Forest Science 132(2): 81-102.

[128] Vacek, S., Vacek, Z., Ulbrichová, I., Remeš, J., Podrázský, V., Vach, M., Bulušek, D., Král, J., Putalová, T. (2019): The effects of fertilization on the health status, nutrition and growth of Norway spruce forests with yellowing symptoms. - Scandinavian Journal of Forest Research 34(4): 267-281.

[129] Vercauteren, K. C., Hyngstrom, S. E. (1998): Effects of agricultural activities and hunting on home ranges of female white-tailed deer. - Journal of Wildlife Management 62(1): 280285.

[130] Vieira, M. E., Conner, M. M., White, G. C., Freddy, D. J. (2003): Effects of archery hunter numbers and opening dates on elk movement. - Journal of Wildlife Management 67: 717728.

[131] Ward, A. I. (2005): Expanding ranges of wild feral deer in Great Britain. - Mammal Review 35: 165-173.

[132] Williams, S. C., DeNicola, A., Almendinger, T., Maddock, J. (2013): Evaluation of Organized Hunting as a Management Technique for Overabundant White-Tailed Deer in Suburban Landscapes. - Wildlife Society Bulletin 37(1): 137-145.

[133] Wrzesień, M., Denisow, B. (2016): The effect of agricultural landscape type on field margin flora in south eastern Poland. - Acta Botanica Croatica 72(2): 217-225. 